\title{
Source and Reduction of Nitrous Oxide
}

Sofia R. Pauleta ${ }^{1}$, Marta S. P. Carepo ${ }^{2}$, Isabel Moura ${ }^{2}$

1 Microbial Stress Lab, UCIBIO, REQUIMTE, Departamento de Química, Faculdade de Ciências e Tecnologia, Universidade Nova de Lisboa, 2829-516 Caparica, Portugal.

2 Biological Chemistry Lab, LAQV, REQUIMTE, Departamento de Química, Faculdade de Ciências e Tecnologia, Universidade Nova de Lisboa, 2829-516 Caparica, Portugal.

Please note: This is a contribution for the special issue in honor of Prof. Armando Pombeiro (VSI: Pombeiro - "Coordination Compounds and Homogeneous Catalysis")

\section{Corresponding Author}

Sofia R. Pauleta

Microbial Stress Lab, UCIBIO, REQUIMTE, Departamento de Química, Faculdade de Ciências e Tecnologia, Universidade Nova de Lisboa, 2829-516 Caparica, Portugal.

E-mail: srp@fct.unl.pt

Tel. +351212948385, ext 10967

Fax +351212948550

Isabel Moura

Biological Chemistry Lab, LAQV, REQUIMTE, Departamento de Química, Faculdade de Ciências e Tecnologia, Universidade Nova de Lisboa, 2829-516 Caparica, Portugal.

E-mail: isabelmoura@fct.unl.pt

Tel. +351212948385 , ext 10916

Fax +351212948550 


\section{Graphical abstract}

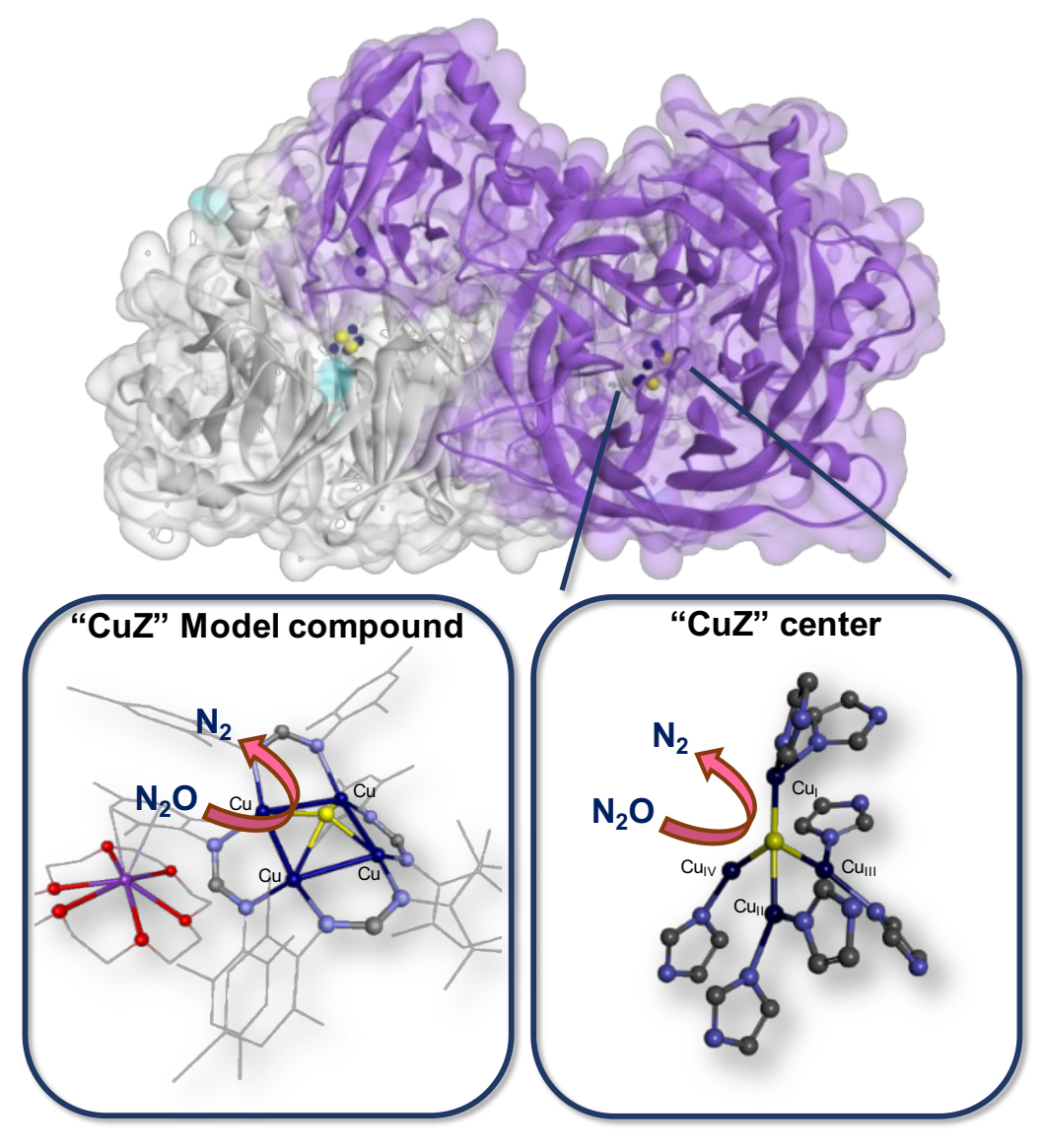

\section{Highlights}

- $\mathrm{N}_{2} \mathrm{O}$ global warming impact is $300 \mathrm{x}$ higher than $\mathrm{CO}_{2}$

- Nitrous oxide reductase has two copper centers, $\mathrm{CuA}$ and " $\mathrm{CuZ}$ "

- "CuZ" center can be isolated as $\mathrm{CuZ} *(4 \mathrm{Cu} 1 \mathrm{~S})$ or as $\mathrm{CuZ}(4 \mathrm{Cu} 2 \mathrm{~S})$

- $\mathrm{CuZ} *(4 \mathrm{Cu} 1 \mathrm{~S})\left[4 \mathrm{Cu}^{1+}\right]$ turnover number explains high reduction rate of whole-cells

- Structural and functional model compounds for nitrous oxide reductase active site 


\section{Contents}

\section{Introduction}

\section{2. $\mathrm{N}_{2} \mathrm{O}$ and its sources}

2.1 Properties of $\mathrm{N}_{2} \mathrm{O}$ and its reactivity

\subsection{Sources of $\mathrm{N}_{2} \mathrm{O}$}

2.3 Inhibition of denitrification by environmental conditions

\section{Enzymes that reduce $\mathrm{N}_{2} \mathrm{O}$}

3.1 Nitrogenase

3.2 Multicopper oxidase

3.3 Nitrous oxide reductase

4. Nitrous oxide reductase - Structure and Catalysis

4.1 Clade I and Clade II $\mathrm{N}_{2} \mathrm{OR}$

4.2 Structure and Biochemical properties Clade I $\mathrm{N}_{2} \mathrm{OR}$

4.3 Activation and Catalysis of Clade $\mathrm{I} \mathrm{N}_{2} \mathrm{OR}$

\section{Model Compounds of $\mathrm{N}_{2} \mathrm{OR}$ "CuZ" center}

5.1 Trinuclear-sulfide copper complexes, [3Cu1S]

5.2 Tetranuclear-sulfide copper complexes, [4Cu1S]

5.3 Copper complexes reactivity towards $\mathrm{N}_{2} \mathrm{O}$

\section{Concluding Remarks}




\begin{abstract}
Nitrous oxide is a potent greenhouse gas with a global warming impact 300 -fold higher than carbon dioxide. Due to its exponential increase in the atmosphere and its implications in climate change there is the need to develop strategies to mitigate its emissions and to reduce it to the inert dinitrogen gas. Only three enzymes have been reported to be able to reduce nitrous oxide, namely nitrogenase, one multicopper oxidase and nitrous oxide reductase, with the latter being the only one with a relevant physiological activity. In this enzyme, reduction of nitrous oxide occurs in a unique catalytic tetranuclear sulfide center, named "CuZ" center, a complex center required to overcome the high activation barrier of this reaction. Nitrous oxide reductase can be isolated with "CuZ" center in two forms, $\mathrm{CuZ} *(4 \mathrm{Cu} 1 \mathrm{~S})$ and $\mathrm{CuZ}(4 \mathrm{Cu} 2 \mathrm{~S})$, that differ in their catalytic and spectroscopic properties. Recently, another step towards a better understanding of the catalytic and activation mechanism of this enzyme was taken by identifying and spectroscopically characterizing an intermediate species of its catalytic cycle, $\mathrm{CuZ}$.

A different approach for $\mathrm{N}_{2} \mathrm{O}$ reduction can be attained by using model compounds. The unique structural motif present in "CuZ" center, a $\mathrm{Cu}_{4}\left(\mu_{4}-\mathrm{S}\right)$, has been a challenge for inorganic synthesis but different synthetic clusters that mimic different forms of "CuZ" center have been reported. Model compounds for the different oxidation states involved in $\mathrm{N}_{2} \mathrm{O}$ reduction are also available. The advances in this area will be discussed in light of the recent data, with structural and functional model compounds of $\mathrm{N}_{2} \mathrm{OR}$ active site.
\end{abstract}

Keywords: Nitrous oxide; Nitrous oxide reductase; $\mathrm{CuA}$ center; $\mathrm{CuZ}$ center; denitrification, $\mathrm{CuZ}$ model compounds 


\section{Introduction}

Nitrous oxide is the second greenhouse gas with the lowest emission levels, $6 \%$, compared to $16 \%$ for methane and $76 \%$ for carbon dioxide, the most abundant, with its emissions being only higher than fluorinated gases that comprise $2 \%$ of the global values [1]. However, $\mathrm{N}_{2} \mathrm{O}$ is a potent greenhouse gas with a global warming potential 300 -fold higher than that of carbon dioxide on the molecular basis over a 100 -year time period $[2,3]$. Therefore, it has a high contribution to global warming and also plays an important role in the ozone layer depletion that occurs in the stratosphere [4-6], as it will be described in Section 2.1.

The atmospheric concentration of $\mathrm{N}_{2} \mathrm{O}$ is currently around $325 \mathrm{ppb}$, and it has been observed an average of $0.25 \%$ increase each year $[4,7,8]$. In fact, its concentration is $20 \%$ higher than that estimated for the pre-industrial era and prior to the introduction of inorganic fertilizers in agriculture [3]. Moreover, $\mathrm{N}_{2} \mathrm{O}$ has a long atmospheric lifetime, and it is estimated that it takes around 120 years to remove $63 \%$ of its initial emissions $[6,7,9]$.

Therefore, strategies developed to reduce its concentration, either by lower its emissions or processes that can degrade it to a less harmful gas have drawn increasing attention in the last decade. Some of these aspects will be discussed here, such as nitrous oxide reactivity with ozone, and which biological pathways and anthropogenic actions contribute the most to its release to the atmosphere. Towards finding a process that can efficiently reduce its concentration, we will focus on the enzymes that have been reported to use $\mathrm{N}_{2} \mathrm{O}$ as its substrate and on copper model compounds that have been designed to mimic the catalytic cycle of one of these enzymes, "CuZ" center, and their ability to reduce $\mathrm{N}_{2} \mathrm{O}$.

\section{2. $\mathrm{N}_{2} \mathrm{O}$ and its sources}

\subsection{Properties of $\mathrm{N}_{2} \mathrm{O}$ and its reactivity}

The $\mathrm{N}_{2} \mathrm{O}$ is a linear asymmetrical molecule with different resonance structures (Scheme 1) [10], which explains its electronic and structural properties. Contrary to carbon dioxide, a symmetrical molecule, $\mathrm{N}_{2} \mathrm{O}$ has a dipole moment of 0.166 Debye, and the interatomic $\mathrm{N}-\mathrm{N}$ and $\mathrm{N}-\mathrm{O}$ distances are shorter than the average values for a double bond, $1.128 \AA$ and $1.184 \AA$, respectively.

This molecule is thermodynamically a potent oxidant, given its reduction potential of $\mathrm{E}^{\mathrm{o}}$ of $1.35 \mathrm{~V}$, at $\mathrm{pH} 7.0$ (Equation 1), but the reaction has a large activation barrier, making it kinetically inert [11]. This activation barrier can be overcome by using metal ions. 


$$
\mathrm{N}_{2} \mathrm{O}+2 \mathrm{e}^{-}+2 \mathrm{H}^{+} \rightarrow \mathrm{N}_{2}+\mathrm{H}_{2} \mathrm{O}, \mathrm{E}^{\mathrm{o}}=1.35 \mathrm{~V}, \mathrm{pH} 7.0
$$

Due to the driving force to find efficient ways to decompose $\mathrm{N}_{2} \mathrm{O}$, heterogenous and homogenous catalysis using metal complexes have been described (some examples can be found in [12-14]), mainly involving non-transition metals, considering that $\mathrm{N}_{2} \mathrm{O}$ is a weak ligand. However, as will be discussed in Section 5, multinuclear copper complexes have also been developed, in this case towards mimicking " $\mathrm{CuZ}$ ", the catalytic center of a highly efficient enzyme in reducing $\mathrm{N}_{2} \mathrm{O}$, nitrous oxide reductase $\left(\mathrm{N}_{2} \mathrm{OR}\right)$ (see Section 4).

Nevertheless, $\mathrm{N}_{2} \mathrm{O}$ can be decomposed in the middle stratosphere through photolysis to nitrogen and $\mathrm{O}\left({ }^{1} \mathrm{D}\right)$ (Equation 3). A minor fraction of $\mathrm{N}_{2} \mathrm{O}$ will react with $\mathrm{O}\left({ }^{1} \mathrm{D}\right)$ forming nitric oxide (Equation 3), at lower altitudes where the photolysis occur $[4,9,15]$.

$$
\begin{aligned}
& \mathrm{N}_{2} \mathrm{O}+h v \rightarrow \mathrm{N}_{2}+\mathrm{O}\left({ }^{1} \mathrm{D}\right) \\
& \mathrm{N}_{2} \mathrm{O}+\mathrm{O}\left({ }^{1} \mathrm{D}\right) \rightarrow 2 \mathrm{NO}
\end{aligned}
$$

This reaction was identified as the major source of reactive nitrogen $\left(\mathrm{NO}_{\mathrm{x}}\right)$, which then reacts with ozone in a catalytic manner, in which a single NO molecule can destroy $10^{3}-10^{5}$ ozone molecules before being converted to a less-reactive molecule $[16,17]$. Other reactive species have also been identified to perform a similar reaction, such as chlorine and hydrogen oxide, but these are dominant in the lower and upper stratosphere, while $\mathrm{N}_{2} \mathrm{O}$ has its maximum concentration in the middle stratosphere at the same site as ozone [15-17]. Therefore, there is a need to reduce $\mathrm{N}_{2} \mathrm{O}$ emissions to enhance the recovery of the ozone layer, which will also have a positive effect on the climate change [4].

\subsection{Sources of $\mathrm{N}_{2} \mathrm{O}$}

The major sources for the increasing concentration of $\mathrm{N}_{2} \mathrm{O}$ in the atmosphere are the oceans, forests and savannas (natural sources), contributing with around $10.5 \mathrm{TgN} / \mathrm{yr}$, followed by agriculture, biomass burning, power plants, waste water treatment plants, combustion engines and nitric acid production (anthropogenic sources), with a release of $5 \mathrm{TgN} / \mathrm{yr}$ year (data for early 1990s, which are expected to rise by 2050) [2, 18, 19].

Most of the natural sources and the ones arising from agriculture are due to the microbial metabolism of nitrogen compounds, and its increase has been attributed to the extensive use of fertilizers after the discovery of the Haber-Bosch process in the beginning of the $20^{\text {th }}$ century [20-22].

The major pathways involved in the release of $\mathrm{N}_{2} \mathrm{O}$ belong to the nitrogen biogeochemical cycle: denitrification and ammonia oxidation to nitrite, which is the first step of the nitrification 
pathway, and to a lesser extend the dissimilatory nitrate reduction to ammonium (DNRA) [2326] (Figure 1). In the nitrification pathway, which occurs under oxic conditions, $\mathrm{N}_{2} \mathrm{O}$ is formed during the oxidation of hydroxylamine, when nitrite is present in low concentrations while ammonia exists in high concentrations [27, 28]. In the DNRA pathway (Figure 1), $\mathrm{N}_{2} \mathrm{O}$ is formed in small amounts concomitantly with ammonium when nitrate/nitrite is being reduced. As will be discussed in Section 4.1, some of these bacteria link $\mathrm{N}_{2} \mathrm{O}$ reduction to dinitrogen with energy conservation [25, 29, 30]. Moreover, chemodenitrification processes can also contribute to the formation of $\mathrm{N}_{2} \mathrm{O}$ (see Section 4.1), through the chemical reaction of nitrite with ferrous iron to form $\mathrm{NO}$, which can then further react with ferrous iron and form $\mathrm{N}_{2} \mathrm{O}$ [31]. The denitrification pathway is the one contributing the most for the release of $\mathrm{N}_{2} \mathrm{O}$, since this molecule is an intermediate in the four-step reduction of nitrate to dinitrogen gas (Figure 1) [32]. However, not all microorganism can perform the complete denitrification, as is the case of fungi [33-35], and some bacteria, which lack the gene encoding the last enzyme of this pathway [36,37], $\mathrm{N}_{2} \mathrm{OR}$ or due to environmental conditions that decrease or inhibit its catalysis [38], such as low pH [39-41], oxygen [42-44], presence of carbon dioxide [45, 46] and sulfide [47].

\subsection{Inhibition of denitrification by environmental conditions}

Denitrification metabolic pathway is an energy conservation pathway allowing the bacteria and fungi to survive under anoxic or near anoxic conditions due to ATP formation coupled to an electrochemical gradient across the cytoplasmic membrane.

Under oxic conditions this pathway is arrested mainly due to gene expression control by FNR/DNR type regulators [43,44], as the reduction of molecular oxygen is energetically advantageous. On the other hand, $\mathrm{pH}$ has been shown to have a post-transcriptional effect, as the expression level of all the genes that encode the enzymes of this pathway do not seem to be affected [41]. Moreover, the enzyme that is mainly affected is $\mathrm{N}_{2} \mathrm{OR}$, leading to release of $\mathrm{N}_{2} \mathrm{O}$ to the atmosphere, but the molecular mechanisms of this inhibition are not yet fully understood. One hypothesis is a post-translational effect, such as copper center assembly, with the enzyme remaining in the apo-form [41], and another is that "CuZ" center cannot be maintained in the active state, though copper incorporation occurs (Carreira, et al. unpublished work).

There are several reports that the presence of sulfide can lead to a decrease in the rate of $\mathrm{N}_{2} \mathrm{O}$ reduction by denitrifying bacteria [47-49]. However, the molecular mechanism for this inhibition is not known. Surprisingly, the catalytic center of $\mathrm{N}_{2} \mathrm{OR}$ can exist in two 
conformations (Section 4.2), $\mathrm{CuZ} *(4 \mathrm{Cu} 1 \mathrm{~S})$ and $\mathrm{CuZ}(4 \mathrm{Cu} 2 \mathrm{~S})$, with a sulfide occupying the substrate binding site in this latter form. In fact, the turnover number of $\mathrm{N}_{2} \mathrm{OR}$ with $\mathrm{CuZ}(4 \mathrm{Cu} 2 \mathrm{~S})$ is smaller than the one of the $\mathrm{N}_{2} \mathrm{OR}$ with $\mathrm{CuZ} *(4 \mathrm{Cu} 1 \mathrm{~S})$, which can explain the low ability of the growing cells in metabolizing $\mathrm{N}_{2} \mathrm{O}$ in the presence of sulfide. Further studies are still required to confirm this hypothesis.

The effect of carbon dioxide in the denitrification pathway is still poorly explored. One study observed the release of $\mathrm{N}_{2} \mathrm{O}$ from Paracoccus denitrificans cultures grown under denitrifying conditions upon increasing $\mathrm{CO}_{2}$ concentration [45]. The authors explained their data considering that $\mathrm{CO}_{2}$ exerts an inhibitory effect on the electron transfer chain by decreasing membrane integrity. This leads to an increase in reactive nitrogen species that decreases gene expression of small electron transfer proteins that require iron, and as a consequence denitrification is also affected [45]. Another possible explanation for the release of $\mathrm{N}_{2} \mathrm{O}$ is that $\mathrm{N}_{2} \mathrm{OR}$ activity is being affected. This enzyme is encoded by the nos operon (Section 4.1), that also presents a gene coding for a Fe/S protein, NosR, that has been proposed to be crucial for $\mathrm{N}_{2} \mathrm{OR}$ activity (NosR, see Section 4.1). Under high $\mathrm{CO}_{2}$ concentrations, the Fe/S centers of NosR might be compromised which would affect the activity of the $\mathrm{N}_{2} \mathrm{OR}$, leading to $\mathrm{N}_{2} \mathrm{O}$ release.

\section{Enzymes that reduce $\mathrm{N}_{2} \mathrm{O}$}

The removal of nitrous oxide from the atmosphere might only be efficiently performed by an enzymatic activity, and only three enzymes have been reported in the literature to be able to use it as a substrate: nitrogenase, multicopper oxidase and $\mathrm{N}_{2} \mathrm{OR}$. These three enzymes are metalloproteins but do not share a similar catalytic center nor these centers have in their composition a common metal, with two of them involved in two distinct pathways of the nitrogen biogeochemical cycle and one of them with still an unassigned physiological function, as will be discussed.

\subsection{Nitrogenase}

Nitrogenase is a metalloenzyme with a complex FeMo cofactor, also named M-cluster ( $\mathrm{MoFe}_{7} \mathrm{~S}_{9} \mathrm{C}$-homocitrate), that catalyzes the reduction of $\mathrm{N}_{2}$ to ammonia $\left(\mathrm{NH}_{3}\right)$ (Figure 1) [50], in the nitrogen fixation pathway. In the early studies of this enzyme, it was shown that $\mathrm{N}_{2} \mathrm{O}$ is a competitive inhibitor of $\mathrm{N}_{2}$ fixation $[51,52]$, but in fact it can interact with the same redox form of nitrogenase as its native substrate, $\mathrm{N}_{2}$, being a substrate of this enzyme $[52,53]$. 
Mechanistic studies showed that $\mathrm{N}_{2} \mathrm{O}$ is reduced by nitrogenase to dinitrogen gas, that is then used by the enzyme as an intermediate substrate, with the end-product being $\mathrm{NH}_{3}$ [52, 54]. Nevertheless, this process does not seem to be biologically relevant, since in Bradyrhizobium sp. 8A55 that produces both active enzymes, $\mathrm{N}_{2} \mathrm{OR}$ and nitrogenase, $\mathrm{N}_{2} \mathrm{O}$ is mainly reduced by the first [55].

\subsection{Multicopper oxidase}

There has been only one report in the literature about the reduction of nitrous oxide by a multicopper oxidase [56]. The enzyme from the archaeon Pyrobaculum aerophilum was heterologously produced in $E$. coli with its copper sites slightly depleted (binding $3.1 \mathrm{Cu} /$ protein instead of the expected $4 \mathrm{Cu}$ /protein) but presenting all the spectroscopic features for the presence of a Type $1 \mathrm{Cu}$, Type 2 and a Type 3 copper center. This enzyme is a metallo-oxidase for $\mathrm{Fe}^{2+}$ and $\mathrm{Cu}^{1+}$, and it can use either molecular oxygen or nitrous oxide as its second substrate [56]. Nevertheless, the end-product of the reaction has still to be identified.

Although, studies under physiological conditions are missing, it is expected that the natural substrate of this enzyme is the molecular oxygen. Thus, the reason for this multicopper oxidase to have evolved the ability to use $\mathrm{N}_{2} \mathrm{O}$ in the oxidation of iron with a higher turnover number than the one attained with molecular oxygen, is still an open question. However, considering that Pyrobaculum aerophilum is an archaeon with the ability to grow under anoxic conditions, and its genome encodes nitrite and nitric oxide reductases, it would be plausible to hypothesize that the generated nitrous oxide could be used by other enzymes for essential metabolic pathways in substitution of molecular oxygen, including ATP synthesis.

Nevertheless, it must be pointed out that the catalytic trinuclear copper center of the multicopper oxidases is coordinated by histidine side chains but the geometry of this center together with the absence of a sulfur atom (either inorganic or from a protein residue) may render it not to be suitable for the binding and activation of $\mathrm{N}_{2} \mathrm{O}$ (see section 4 and 5).

Thus, since a metal center is usually required for an efficient catalysis of $\mathrm{N}_{2} \mathrm{O}$ reduction (see section 4 and 5) either the substrate binds in a different mode or the catalytic mechanism is different originating other products then dinitrogen and water. In any case, further physiological or theoretical studies are required to answer these questions. 


\subsection{Nitrous oxide reductase}

Similarly to the multicopper oxidase, $\mathrm{N}_{2} \mathrm{OR}$ is also a copper enzyme with two copper centers. In this case, $\mathrm{CuA}$ center (a binuclear copper center) act as the electron transferring center to the catalytic center, "CuZ" center, which is a tetranuclear copper sulfide center unique in Nature. From the three enzymes that can reduce $\mathrm{N}_{2} \mathrm{O}, \mathrm{N}_{2} \mathrm{OR}$ is the most efficient and the only one shown up-to-now to be biologically relevant in Nature.

This enzyme catalyzes the reduction of $\mathrm{N}_{2} \mathrm{O}$ to dinitrogen according to Eq. 1 (see Section 2.1, Figure 1). This favorable reaction, with a highly negative free energy change $\left(\Delta G^{\text {ol }}=-339.5\right.$ $\mathrm{kJ} / \mathrm{mol}$ ) [57, 58], is a spin-forbidden process [11], and thus has a large activation barrier of around $250 \mathrm{~kJ} / \mathrm{mol}$ [59], that is overcome by taking place at the special metal center, "CuZ".

This reaction is the last step of the denitrification metabolic pathway that is used by the microorganisms to produce a proton-driven force for ATP synthesis, under anoxic conditions [60].

\section{Nitrous oxide reductase - Structure and Catalysis}

\subsection{Clade I and Clade II $\mathrm{N}_{2} \mathrm{OR}$}

Based on the gene organization of the $\operatorname{nos} Z$ operon encoding $\mathrm{N}_{2} \mathrm{OR}$, these enzymes have been divided into two clades (Figure 2).

Clade I $\mathrm{N}_{2} \mathrm{OR}$ have been isolated from different proteobacteria of the $\alpha-, \beta$-, and $\gamma$-division [61], that in most cases also encode genes for the other enzymes of the denitrification pathway. Most of the biochemical, structural and mechanistic studies reported in the literature were performed using Clade I $\mathrm{N}_{2} \mathrm{ORs}$.

Clade II $\mathrm{N}_{2} \mathrm{OR}$ has been identified in the genome of proteobacteria of the $\delta$ - and $\varepsilon$-division and also in Gram-positive bacteria, such as Geobacillus thermodenitrificans and other Bacillus species [62-64]. These organisms are considered canonical non-denitrifiers as they lack nirS and $n i r K$ genes, that encode the known nitrite reductase enzymes associated with denitrification $[29,30,36,57]$. Most of the studies on Clade II $\mathrm{N}_{2} \mathrm{OR}$ focused on Dechloromonas aromatica and Anaeromyxobacter dehalogenans [30, 31] physiology, and only $\mathrm{N}_{2} \mathrm{OR}$ from Wolinella succinogenes [65] has been isolated (being also the first reported Clade $\mathrm{II}_{2} \mathrm{OR}$ ), showing that in this particular case $\mathrm{N}_{2} \mathrm{OR}$ binds a $c$-type heme in an additional C-terminus domain [65-70]. Some Clade II microorganisms encode a different type of nitrite reductase (NrfA), which catalyzes the last reaction of the dissimilatory nitrite ammonification pathway [29, 71-73], coupling its growth to nitrite reduction to $\mathrm{NH}_{4}{ }^{+}$. Recently, it has been shown that $A$. 
dehalogenans besides this pathway, links abiotic to biotic reactions to convert nitrite to dinitrogen gas, in a process that involves reduction of $\mathrm{Fe}^{3+}$ to $\mathrm{Fe}^{2+}$ to abiotically reduce nitrite generating $\mathrm{N}_{2} \mathrm{O}$, that is then reduced by $\mathrm{N}_{2} \mathrm{OR}$ [31]. Such a process might be common among Clade II microorganisms, which thus can no longer be classified as non-denitrifiers.

One clear difference between Clade I and Clade II $\mathrm{N}_{2} \mathrm{OR}$ is the affinity of the enzyme to $\mathrm{N}_{2} \mathrm{O}$, with Clade II having a higher affinity $(0.1 \mu \mathrm{M})$ than Clade I (around $20 \mu \mathrm{M}$ ), but a lower maximum rate of reaction $[30,74]$. Another difference between the two enzymes is the signal peptide for protein transport to the periplasm of the enzymes encoded by Gram-negative bacteria, which is Sec-dependent (Sec stands for secretory pathway) for Clade II $\mathrm{N}_{2} \mathrm{OR}$, while Clade I $\mathrm{N}_{2} \mathrm{OR}$ signal peptide is recognized by the Twin-arginine translocation (Tat) system. In the latter, the enzyme is transported in the folded state, while in the former it is transported in the unfolded form, which is a requirement for attaching a $c$-type heme to the polypeptide chain as in the case of $W$. succinogenes $\mathrm{N}_{2} \mathrm{OR}$. However, such a signal peptide is also present in the primary sequence of other Clade II $\mathrm{N}_{2} \mathrm{OR}$ that lack the - $\mathrm{CXXCH}$ - canonical $c$-type heme binding motif, for which there is not yet a clear reason. In the case of Gram-positive bacteria, clade II N2OR has been predicted to be membrane associated.

As mentioned, these two clades differ in the gene organization and gene composition of the nos operon that contains nos $Z$ (gene encoding $\mathrm{N}_{2} \mathrm{OR}$ ) (Figure 2). The nos operon of Clade I presents genes that are proposed to encode proteins involved in the "CuZ" center assembly (nosDFYL) and in maintaining $\mathrm{N}_{2} \mathrm{OR}$ in an active state or functioning as an electron donor to the enzyme (nosR) (Figure 1A) [57]. The Clade II nos operon has additional genes, that encode $c$-type cytochromes and nosHG, which are homologues to genes encoding quinol dehydrogenase NapHG [75], that have been proposed to constitute the electron transport chain from menaquinol to $\mathrm{N}_{2} \mathrm{OR}[65,76]$ (Figure $1 \mathrm{~B}$ ).

The identification of clade II $\mathrm{N}_{2} \mathrm{OR}$ microorganisms shows that the ability to reduce nitrous oxide might be more widely spread $[25,36]$, than previously thought. These microorganisms have been considered sinks for $\mathrm{N}_{2} \mathrm{O}$, contrary to the denitrifiers (some harboring clade $\mathrm{I}_{2} \mathrm{OR}$ ) that are sources but also sinks for this gas. Nevertheless, the discovery of the abiotic to biotic coupled denitrification process in these canonical non-denitrifiers, poses questions related to their role in the global consumption of $\mathrm{N}_{2} \mathrm{O}$. Therefore, to better understand the ecological controls on $\mathrm{N}_{2} \mathrm{O}$ emissions and greenhouse effect it is an urge to continue to physiologically and genetically characterize the microorganisms from these two clades, together with the biochemical and kinetic characterization of these different types of $\mathrm{N}_{2} \mathrm{ORs}$. 


\subsection{Structure and Biochemical properties Clade $\mathrm{I} \mathrm{N}_{2} \mathrm{OR}$}

$\mathrm{N}_{2} \mathrm{ORs}$ belonging to Clade I $\mathrm{N}_{2} \mathrm{OR}$ have been isolated from different species and extensively biochemically characterized with their structure determined in different oxidation states, in the presence of iodide and of $\mathrm{N}_{2} \mathrm{O}$ [77-80]. These enzymes have been studied using different spectroscopic techniques and its kinetic parameters determined using either an artificial or its proposed electron donor. On the other hand, $\mathrm{N}_{2} \mathrm{ORs}$ of clade II have only been isolated from $W$. succinogenes [66] and its structure has not yet been determined (only a model structure has been proposed [81]). Therefore, the next two sections will focus on Clade $\mathrm{I} \mathrm{N}_{2} \mathrm{OR}$, that will be referred from now-on simply as $\mathrm{N}_{2} \mathrm{OR}$.

This enzyme was isolated for the first time from Alcaligenes faecalis as a new type of copper containing protein [82], but its activity was only reported 10 years later for a similar protein isolated from Pseudomonas stutzeri [83]. Since then, $\mathrm{N}_{2} \mathrm{OR}$ has been isolated from several denitrifiers and it was shown to be a periplasmic dimeric enzyme that binds 12 copper atoms per dimer. These copper atoms are distributed into two copper centers: "CuZ", the active center, and $\mathrm{CuA}$, the electron transferring center.

The analysis of $\mathrm{N}_{2} \mathrm{OR}$ primary sequence together with its X-ray structure revealed that these two copper centers are organized in two different domains of the enzyme: "CuZ" center in the middle of the N-terminal seven-bladed $\beta$-propeller folded domain (Figure 3A), while $\mathrm{CuA}$ center is bound to the C-terminal cupredoxin-like folded domain. The analysis of these structures also explains why this enzyme is a functional dimer, since the "head-to-tail" arrangement of the monomers, places $\mathrm{CuA}$ and $\mathrm{CuZ}$ centers $10 \AA$ apart [77], which is a distance compatible with an efficient "inter-subunit" electron transfer (Figure 3A) [84]. The distance between CuA and "CuZ" center from the same subunit is about $40 \AA$.

$\mathrm{CuA}$ is a binuclear copper center, with the copper atom $\mathrm{CuA}_{1}$ coordinated by $\mathrm{N}^{\varepsilon 2}$ of a histidine (His526) and $\mathrm{S}^{\delta}$ of a methionine (Met572), while the copper atom $\mathrm{CuA}_{2}$ is coordinated by $\mathrm{N}^{\varepsilon 2}$ of a histidine (His569) and the carbonyl atom of a tryptophan (Trp563). The two copper atoms are also coordinated by two bridging $\mathrm{S}^{\gamma}$ atoms of two cysteine side-chains (Cys561 and Cys565) (numbering of the residues is according to the primary sequence of $P$. denitrificans $\mathrm{N}_{2} \mathrm{OR}$ [78]) (Figure 3B). This center is bound to the C-terminal domain in the loop region between the $\beta 8$ and $\beta 9$ strands of its $\beta$-barrel structure [77].

The CuA center has spectroscopic properties similar to the ones observed for this center in cytochrome $c$ oxidase [85] and quinol $\mathrm{CuA}$ nitric oxide reductase [86]. Its visible spectrum is 
characterized in the oxidized form by maximum absorption bands at 480, 540 and $800 \mathrm{~nm}$ ( $\varepsilon_{480 \mathrm{~nm}}, \varepsilon_{540 \mathrm{~nm}}$ and $\varepsilon_{800 \mathrm{~nm}}$ is $4.0,4.0$ and $3.0 \mathrm{mM}^{-1} \mathrm{~cm}^{-1}$, respectively), which disappear in the reduced form, as both coppers are in the $\mathrm{Cu}^{1+}$ oxidation state (in a $\mathrm{d}^{10}$ electronic configuration) $[87,88]$. In the oxidized form, the electron paramagnetic resonance (EPR) spectrum of CuA center has a characteristic axial signal with a seven-line hyperfine coupling in the $g_{\|}$region (with $g_{\|}=2.18, g_{\perp} \approx 2.03$ and $A \|=3.8 \mathrm{mT}$ ), due to the unpaired electron $(\mathrm{S}=1 / 2)$ that is shared between the two equivalent copper nuclei $(I=3 / 2)$, while it is EPR silent in the reduced form [89-91]. The reduction potential of $\mathrm{CuA}$ center has been determined by potentiometric titrations followed by visible and EPR spectra to be around + $250 \mathrm{mV}$ vs SHE, at pH 7.5 [89, 92, 93], for the redox couple $\left[1 \mathrm{Cu}^{1.5+}: 1 \mathrm{Cu}^{1.5+}\right] /\left[1 \mathrm{Cu}^{1+}: 1 \mathrm{Cu}^{1+}\right]$.

The catalytic center of $\mathrm{N}_{2} \mathrm{OR}$, "CuZ" center, being a tetranuclear copper center bridged by a sulfur atom, is unique in Nature and has only been identified in this enzyme, in opposition to $\mathrm{CuA}$ center $[94,95]$.

The presence of four copper atoms in "CuZ" center raises the possibility that this center could exist in five different oxidation states (Scheme 3). However, only three of these have been observed in isolated enzymes $\left(\left[2 \mathrm{Cu}^{2+}: 2 \mathrm{Cu}^{1+}\right],\left(\left[1 \mathrm{Cu}^{2+}: 3 \mathrm{Cu}^{1+}\right]\right)\right.$ or obtained in vitro $\left(\left[4 \mathrm{Cu}^{1+}\right]\right)$. Moreover, $\mathrm{N}_{2} \mathrm{OR}$ has been isolated with "CuZ" center in two different forms, $\mathrm{CuZ} *(4 \mathrm{Cu} 1 \mathrm{~S})$ and $\mathrm{CuZ}(4 \mathrm{Cu} 2 \mathrm{~S})$, that differ in their structure, as well as in their spectroscopic, redox and kinetic properties. However, $\mathrm{N}_{2} \mathrm{OR}$ has never been isolated with " $\mathrm{CuZ}$ " center in a single form, but usually the samples are richer in either $\mathrm{CuZ}(4 \mathrm{Cu} 2 \mathrm{~S})$, when the enzyme is isolated under anoxic conditions [92], or in $\mathrm{CuZ} *(4 \mathrm{Cu} 1 \mathrm{~S})$ when oxic conditions are used or the cell mass was stored for a long time at low temperature prior to enzyme isolation $[92,96] . \mathrm{N}_{2} \mathrm{OR}$ with " $\mathrm{CuZ}$ " center mainly in the $\mathrm{CuZ} *(4 \mathrm{Cu} 1 \mathrm{~S})$ has also been reported in a $P$. denitrificans double knockout mutant in nosXnirX [97] and more recently from Marinobacter hydrocarbonoclasticus grown at pH 6.5 (sub-optimum pH for this marine bacterium, Carreira et al. unpublished data).

The structure of "CuZ" center was revealed for the first time when the X-ray structure of $M$. hydrocarbonoclasticus $\mathrm{N}_{2} \mathrm{OR}$ with "CuZ" center mainly as $\mathrm{CuZ} *(4 \mathrm{Cu} 1 \mathrm{~S})$ was reported [77]. Although, the tetranuclear copper structure was identified, the bridging atom was first assigned to an oxygen. Such structure could not explain the recent sulfur quantifications and spectroscopic properties reported for Pseudomonas stutzeri $\mathrm{N}_{2} \mathrm{OR}$ [98-100], leading to the reanalysis of the $M$. hydrocarbonoclasticus $\mathrm{N}_{2} \mathrm{OR}$ structure. This analysis together with the determination of the $P$. denitrificans $\mathrm{N}_{2} \mathrm{OR}$ X-ray structure and sulfur quantifications on both 
enzymes [78], showed that "CuZ" center is a tetranuclear $\mu_{4}$-sulfide-bridged copper center, adopting a distorted tetrahedral geometry.

Each of the four copper atoms are coordinated by two conserved histidine residues (located at the $\mathrm{N}$-terminal domain), except $\mathrm{Cu}$ IV that is coordinated by only one. These copper atoms are coordinated by either $\mathrm{N}^{\varepsilon 2}$ (His80, His128, His270, His325, His376) or $\mathrm{N}^{\delta 1}$ (His79 and His437) of the histidine imidazole ring (numbering of the residues is according to the primary sequence of $P$. denitrificans $\mathrm{N}_{2} \mathrm{OR}$ ) and there is also a solvent derived molecule bridging $\mathrm{Cu}_{\mathrm{I}}$ and $\mathrm{Cu}_{\mathrm{IV}}$ (Figure 3C). These histidine residues are located in the blades (His79, His80, His128, His325 and His376) or in the top (His270 and His437) of the $\beta$-propeller N-terminal domain [77-80]. The structure of $\mathrm{CuZ}(4 \mathrm{Cu} 2 \mathrm{~S})$ was only revealed 10 years later, when the structure of $P$. stutzeri $\mathrm{N}_{2} \mathrm{OR}$ isolated under anoxic conditions was reported. The structure was determined for the enzyme in the fully oxidized form, with " $\mathrm{CuZ}$ " center in the $\left[2 \mathrm{Cu}^{2+}: 2 \mathrm{Cu}^{1+}\right]$ oxidation state, and the main difference lied in the $\mathrm{Cu}_{\mathrm{I}}$ and $\mathrm{Cu}_{\mathrm{IV}}$ bridging atom, which was identified to be a sulfur atom [80] (Figure 3C). It is worth mentioning that the coordination sphere of $\mathrm{CuA} 1$ of $\mathrm{CuA}$ center is also different, with the imidazole ring of His583 (equivalent to His526 in $P$. denitrificans) rotated away by $\sim 130^{\circ}$, no longer coordinating this atom (Figure 3B) [80] and hydrogen bonded to the highly conserved S550 and S576. Such a configuration of the polypeptide chain has also been observed in the apo-form of P. stutzeri $\mathrm{N}_{2} \mathrm{OR}$ [101], but its physiologic relevance is still elusive.

The structural difference between $\mathrm{CuZ} *(4 \mathrm{Cu} 1 \mathrm{~S})$ and $\mathrm{CuZ}(4 \mathrm{Cu} 2 \mathrm{~S})$ also translates into differences in their redox, spectroscopic and kinetic properties. In $\mathrm{CuZ} *(4 \mathrm{Cu} 1 \mathrm{~S})$ the oxidation state of the four copper atoms was determined by $\mathrm{Cu} \mathrm{K}$-edge X-ray absorption spectroscopy to be $\left[1 \mathrm{Cu}^{2+}: 3 \mathrm{Cu}^{1+}\right][102]$, which exhibits an absorption band at $640 \mathrm{~nm}\left(\varepsilon_{640 \mathrm{~nm}}\right.$ of around $3.5 \mathrm{mM}^{-}$ ${ }^{1} \mathrm{~cm}^{-1}$ per monomer) and a broad axial EPR signal $\left(g_{\|}=2.16\right.$ and $\left.g_{\perp} \approx 2.04\right)$ with poorly resolved hyperfine-split lines in the parallel region [96, 99, 102-105] (Table 1). This center has been characterized using different spectroscopic techniques, Q-band EPR, magnetic circular dichroism (MCD), resonance Raman, which together with Density Functional Theory (DFT) calculations, based on the structure of this center, helped interpret its properties $[100,102,106-$ $108]$ and concluded that the spin density $\left(S_{\text {Total }}=1 / 2\right)$ is partially delocalized over $\mathrm{Cu}_{\mathrm{I}}(26 \%)$ and $\mathrm{Cu}_{\mathrm{IV}}(13 \%)$, with $29 \%$ being over the bridging sulfur [109]. Moreover, the identification of the nature of the $\mathrm{Cu}_{\mathrm{I}}-\mathrm{Cu}_{\mathrm{IV}}$ edge has only been possible examining the DFT models of $\mathrm{CuZ}^{*}(4 \mathrm{Cu} 1 \mathrm{~S})$ with different edge ligands (bridging water molecule, water molecule bound to $\mathrm{Cu}_{\mathrm{I}}$, bridging $\mathrm{OH}^{-}$, bridging $\mathrm{OH}^{-}$bonded to a lysine residue or a $\mathrm{OH}^{-}$ligand $\mathrm{H}$-bonded to a 
protonated lysine residue) $[102,107,108]$. This analysis concluded that the model that explains the spectroscopic properties of $\mathrm{CuZ}^{*}(4 \mathrm{Cu} 1 \mathrm{~S})$ is the one with a $\mathrm{OH}^{-}$ligand occupying the $\mathrm{Cu}_{I^{-}}$ $\mathrm{Cu}_{\mathrm{IV}}$ edge, but closer to $\mathrm{Cu}_{\mathrm{I}}(2.00 \AA)$ than to $\mathrm{Cu}_{\mathrm{IV}}(2.09 \AA)$, and with the residues $\mathrm{K} 397$ and E435 H-bonded to each other [108, 110] (residues numbered according to P. denitrificans $\mathrm{N}_{2} \mathrm{OR}$ primary sequence).

In addition, this center cannot be easily reduced in vitro in the presence of just sodium dithionite (- $471 \mathrm{mV} v s$ SHE at $\mathrm{pH} 7.0$ [111]), but after a prolonged incubation with reduced methyl or benzyl viologen, the $\left[4 \mathrm{Cu}^{1+}\right]$ oxidation state is attained (Table 1). Nevertheless, the redox potential of the $\left[1 \mathrm{Cu}^{2+}: 3 \mathrm{Cu}^{1+}\right] /\left[4 \mathrm{Cu}^{1+}\right]$ pair could not be determined by potentiometry as it is an "irreversible" process.

$\mathrm{N}_{2} \mathrm{OR}$ has been isolated with " $\mathrm{CuZ}$ " center as $\mathrm{CuZ}(4 \mathrm{Cu} 2 \mathrm{~S})$ either in the $\left[2 \mathrm{Cu}^{2+}: 2 \mathrm{Cu}^{1+}\right]$ or $\left[1 \mathrm{Cu}^{2+}: 3 \mathrm{Cu}^{1+}\right]$ oxidation state, which has a reduction potential of $+60 \mathrm{mV}$, at $\mathrm{pH} 7.5$ [92], but the $\left[4 \mathrm{Cu}^{1+}\right]$ oxidation state has never been reached, even in vitro. The oxidized state is characterized by an absorption band at $550 \mathrm{~nm}\left(5.0 \mathrm{mM}^{-1} \mathrm{~cm}^{-1}\right)$, while the reduced state has an absorption band at around $670 \mathrm{~nm}\left(3.0-4.4 \mathrm{mM}^{-1} \mathrm{~cm}^{-1}\right)$ (Table 1) $[92,110,112]$. Relative to the $\mathrm{X}$-band EPR spectrum, the only EPR active state is $\left[1 \mathrm{Cu}^{2+}: 3 \mathrm{Cu}^{1+}\right]$, since $\mathrm{CuZ}(4 \mathrm{Cu} 2 \mathrm{~S})$ in the $\left[2 \mathrm{Cu}^{2+}: 2 \mathrm{Cu}^{1+}\right]$ was shown to be diamagnetic by MCD. The EPR spectrum exhibits an axial signal $\left(g_{\|}>g \perp>2.0\right)$ with five evenly spaced hyperfine lines being observed in the $g \|$ region [110]. This signal has been interpreted considering three identical hyperfine coupling constants of $5.6 \mathrm{mT}$ [110], with the spin density being distributed over $\mathrm{Cu}_{\mathrm{I}}(17 \%), \mathrm{Cu}_{\mathrm{II}}(11 \%)$ and $\mathrm{Cu}_{\mathrm{IV}}$ (10\%), with the remaining spin density being over $\mu_{4}$-sulfide $(34 \%), \mu_{2}-\mathrm{SH}^{-}(16 \%)$ and $\mathrm{Cu}_{\mathrm{III}}$ (6\%) [110].

The $\mathrm{pH}$ profile of the resonance Raman spectra combined with DFT calculations showed that the protonation state of the edge ligand in $\mathrm{CuZ}(4 \mathrm{Cu} 2 \mathrm{~S})$ is different in the two-oxidation states. In the oxidized state, $\left[2 \mathrm{Cu}^{2+}: 2 \mathrm{Cu}^{1+}\right], \mathrm{Cu}_{\mathrm{I}}-\mathrm{Cu}_{\mathrm{IV}}$ edge is a sulfide $\left(\mu_{2} \mathrm{~S}^{2-}\right)$ with a $\mathrm{p} K_{\mathrm{a}} \leq 3[110]$, while in the $\left[1 \mathrm{Cu}^{2+}: 3 \mathrm{Cu}^{1+}\right]$ oxidation state, it is occupied by a hydrosulfide $\left(\mu_{2} \mathrm{SH}^{-}\right)$with a $\mathrm{p} K_{\mathrm{a}}$ $\geq 11$, as it was possible to observe $\mathrm{D}_{2} \mathrm{O}$-isotope sensitive vibration modes, identified as $\mathrm{S}-\mathrm{H}$ bending-modes [110].

\subsection{Activation and Catalysis of Clade $\mathrm{I} \mathrm{N}_{2} \mathrm{OR}$}

The hypothesis that isolated Clade $\mathrm{I}_{2} \mathrm{OR}$ requires activation came from the observation that crude cell extracts can reduce exogenously provided $\mathrm{N}_{2} \mathrm{O}$ at a high rate, ranging from 48 to 72 $\mu \mathrm{mol}$ of $\mathrm{N}_{2} \mathrm{O} / \mathrm{min} / \mathrm{mg}_{\mathrm{N} 2 \mathrm{OR}}[74,89,113]$, while the isolated enzyme with "CuZ" center with 
different ratios of $\mathrm{CuZ} *(4 \mathrm{Cu} 1 \mathrm{~S})$ to $\mathrm{CuZ}(4 \mathrm{Cu} 2 \mathrm{~S})$ has very low specific activities, ranging from 1 and $10 \mu \mathrm{mol}$ of $\mathrm{N}_{2} \mathrm{O} / \mathrm{min} / \mathrm{mg}_{\mathrm{N} 2 \mathrm{OR}}[89,92,112,114,115]$. Thus, these later values must correspond to an unready state of the enzyme [116]. However, a high specific activity of 160 $\mu \mathrm{mol}$ of $\mathrm{N}_{2} \mathrm{O} / \mathrm{min} / \mathrm{mg}_{\mathrm{N} 2 \mathrm{OR}}$ was reported for clade II $W$. succinogenes $\mathrm{N}_{2} \mathrm{OR}[66,69]$, which could indicate that this enzyme does not require activation.

Activation of Clade I $\mathrm{N}_{2} \mathrm{OR}$ has been observed after a prolonged incubation with reduced viologens [117, 118]. These first experiments clearly showed that during this reduction $\mathrm{CuZ}^{*}(4 \mathrm{Cu} 1 \mathrm{~S})$ in the $\left[1 \mathrm{Cu}^{2+}: 3 \mathrm{Cu}^{1+}\right]$ oxidation state was being reduced to $\left[4 \mathrm{Cu}^{1+}\right]$, since the increase in activity was concomitant with the decrease of the EPR signal, as a diamagnetic EPR silent species was being generated, $\left[4 \mathrm{Cu}^{1+}\right]$ (all copper atoms are in a $\mathrm{d}^{10}$ electronic configuration) [117]. This activation process has a rate constant of $1.2 \times 10^{-3} \mathrm{~s}^{-1}$ at $\mathrm{pH} 7.0$ [117], which is too slow to be part of the catalytic cycle $[118,119]$, while the turnover number of $\mathrm{CuZ}^{*}(4 \mathrm{Cu} 1 \mathrm{~S})$ in the $\left[4 \mathrm{Cu}^{1+}\right]$ oxidation state was estimated to be $320 \mathrm{~s}^{-1}$ [119]. In the case of $\mathrm{CuZ}(4 \mathrm{Cu} 2 \mathrm{~S})$, the only catalytically competent oxidation state is $\left[1 \mathrm{Cu}^{2+}: 3 \mathrm{Cu}^{1+}\right]$, but its turnover number is much smaller, $0.6 \mathrm{~h}^{-1}$ [119].

Therefore, the only form of "CuZ" center that is catalytically relevant in vitro is $\mathrm{CuZ} *(4 \mathrm{Cu} 1 \mathrm{~S})$ in the $\left[4 \mathrm{Cu}^{1+}\right]$ oxidation state. The enzyme with " $\mathrm{CuZ}$ " center in this oxidation state reacts with $\mathrm{N}_{2} \mathrm{O}$, generating $\mathrm{N}_{2}$, that can be detected by GC-MS, and $\mathrm{CuA}$ and " $\mathrm{CuZ}$ " centers re-oxidize, as observed by the partial re-appearance of its EPR and visible spectral features [118].

The kinetic parameters of $\mathrm{N}_{2} \mathrm{OR}$ with " $\mathrm{CuZ}$ " center as $\mathrm{CuZ} *(4 \mathrm{Cu} 1 \mathrm{~S})$ [4 $\left.\mathrm{Cu}^{1+}\right]$, using methyl viologen as electron donor were estimated for several enzymes [58]. In the case of $M$. hydrocarbonoclasticus $\mathrm{N}_{2} \mathrm{OR}$, a $\mathrm{K}_{\mathrm{M}}$ of $18 \mu \mathrm{M}$ and a $\mathrm{V}_{\mathrm{M}}$ of $200 \mu \mathrm{mol}$ of $\mathrm{N}_{2} \mathrm{O} / \mathrm{min} / \mathrm{mg}_{\mathrm{N} 2 \mathrm{OR}}$ were estimated [120]. These values corroborate the hypothesis that this is the active form of the enzyme in vivo, as a similar $\mathrm{K}_{\mathrm{M}}$ was observed for these cells in the reduction of exogenously added $\mathrm{N}_{2} \mathrm{O}$, and considering the yield of the enzyme purification, such a $\mathrm{V}_{\mathrm{M}}$ explains the high reduction rate observed for cells actively denitrifying [74].

The catalytic cycle of $\mathrm{CuZ} *(4 \mathrm{Cu} 1 \mathrm{~S})$ has been proposed recently (Figure 4), which starts with the "CuZ" center in the fully reduced state, $\left[4 \mathrm{Cu}^{1+}\right]$ (intermediate 1 ), and reacting with the substrate, $\mathrm{N}_{2} \mathrm{O}$, forming intermediate 2. During this process, $\mathrm{N}_{2} \mathrm{O}$ binds with its terminal $\mathrm{N}$ to $\mathrm{Cu}_{\mathrm{I}}$ in a linear configuration [121], and elongation of the N-O bond leads to the rearrangement of its structure, so that it binds at the $\mathrm{Cu}_{\mathrm{I}}-\mathrm{Cu}_{\mathrm{IV}}$ edge in a $\mu-1,3-\mathrm{N}_{2} \mathrm{O}$ coordination forming a $139^{\circ}$ 
angle. In this intermediate 2, the oxygen atom is H-bonded to the protonated form of Lys397 $[117,122]$.

For the release of $\mathrm{N}_{2}$ two electrons will be transferred, via $\mathrm{Cu}_{\mathrm{IV}}$, from the fully reduced $\mathrm{CuZ} *(4 \mathrm{Cu} 1 \mathrm{~S})\left[4 \mathrm{Cu}^{1+}\right]$, in a proton coupled process, with all four-copper atoms of "CuZ" center being involved [121]. The cleavage of the N-O requires one electron, with one proton being simultaneously transferred from Lys397 to the oxygen, that becomes coordinated to $\mathrm{Cu}_{\mathrm{IV}}$ as a hydroxide. The second electron is transferred, cleaving the $\mathrm{Cu}_{\mathrm{I}}-\mathrm{N}$ bond and leading to the release of $\mathrm{N}_{2}$. Re-protonation of Lys397, with a proton from the solvent, coupled with electron transfer from $\mathrm{CuA}$ leads to the formation of $\mathrm{CuZ}^{0}$, intermediate 3 . In this intermediate, the protonated form of Lys397 is H-bonded to the hydroxide ligand of $\mathrm{Cu}_{\mathrm{IV}}$, and to Glu435, stabilizing $\mathrm{CuZ}^{0}[121]$. The catalytic cycle is closed by the rapid intramolecular electron transfer via $\mathrm{CuA}$ center $\left(k_{I E T}>0.1 \mathrm{~s}^{-1}\right)[121]$.

$\mathrm{CuZ}^{0}$, intermediate 3 , was first isolated when reacting the fully reduced $\mathrm{CuZ} *(4 \mathrm{Cu} 1 \mathrm{~S})\left[4 \mathrm{Cu}^{1+}\right]$ with an equimolar amount of $\mathrm{N}_{2} \mathrm{O}$ and observing the formation of a short-lived species with a visible spectrum with a maximum absorption band at $680 \mathrm{~nm}\left(2.0 \mathrm{mM}^{-1} \mathrm{~cm}^{-1}\right)$, and other absorption bands at 480, 540 and $800 \mathrm{~nm}$, corresponding to the oxidized $\mathrm{CuA}$ center [93]. The EPR spectrum of $\mathrm{CuZ}^{0}$ has an axial signal that after removal of the $\mathrm{CuA}$ contribution can be simulated with a $g_{\|}=2.177>g_{\perp}=2.05>2.0$ [93], and two equal hyperfine coupling constants $(A \|=4.2 \mathrm{mT})$ to account for the 6-line hyperfine pattern in the parallel region [121] (Table 1). This species was also characterized by resonance Raman and MCD spectroscopies indicating that " $\mathrm{CuZ}$ " center is in the $\left[1 \mathrm{Cu}^{2+}: 3 \mathrm{Cu}^{1+}\right]$ oxidation state [121]. However, its coordination is different from $\mathrm{CuZ} *(4 \mathrm{Cu} 1 \mathrm{~S})$ in the same oxidation sate, with a hydroxide ligand being bound to $\mathrm{Cu}_{\mathrm{IV}}$, which leads to a more homogenous spin distribution between $\mathrm{Cu}_{\mathrm{I}}$ and $\mathrm{Cu}_{\mathrm{IV}}$ when compared with $\mathrm{CuZ} *(4 \mathrm{Cu} 1 \mathrm{~S})\left[1 \mathrm{Cu}^{2+}: 3 \mathrm{Cu}^{1+}\right][121]$.

$\mathrm{CuZ}^{0}$ can be reduced to the fully reduced form, $\left[4 \mathrm{Cu}^{1+}\right]$, using a physiologically relevant artificial electron donor, sodium ascorbate [121]. This reduction occurs through a rapid intramolecular electron transfer indicating that its reduction potential must be $>0 \mathrm{mV}$ and thus, compatible with the reduction potential of the periplasm.

In fact, Clade I $\mathrm{N}_{2} \mathrm{OR}$ can accept electrons from periplasmic small $c$-type cytochromes [123$125]$ or type 1 copper proteins $[123,126]$, depending on the microorganism, and mitochondria cytochrome $c$ can also be used in some cases as an artificial electron donor [120, 127, 128]. Whole-cells studies have shown that during $\mathrm{N}_{2} \mathrm{O}$ reduction there is oxidation of a cytochrome in the case of Rhodobacter capsulatus, Rhodobacter sphaeroides and P. denitrificans [124, 
129] and that a cytochrome $c_{2}$ knock-out mutant in $R$. capsulatus was unable to reduce $\mathrm{N}_{2} \mathrm{O}$ [125].

The involvement of these small electron donors does not exclude that in vivo there are other proteins also involved in the electron transfer chain (Figure 1A), such as NosR, which has been shown to form a supramolecular complex with $\mathrm{N}_{2} \mathrm{OR}$ in Pseudomonas aeruginosa, together with other reductases of the denitrification pathway $[130,131]$. NosR has been shown to be essential for the whole cells to maintain the ability to reduce $\mathrm{N}_{2} \mathrm{O}$, and $\mathrm{N}_{2} \mathrm{OR}$ isolated from nos $R$ knock-out strains has "CuZ" center as $\mathrm{CuZ} *(4 \mathrm{Cu} 1 \mathrm{~S})$ contrary to the wild-type strain, in which "CuZ" center is as $\mathrm{CuZ}(4 \mathrm{Cu} 2 \mathrm{~S})$ (in both cases the enzyme was purified under anoxic conditions) [132]. Thus, NosR, a Fe/S and flavin containing protein [132, 133], might be involved in maintaining $\mathrm{N}_{2} \mathrm{OR}$ in an active state, but it might also be involved in the electron transfer chain mediating the electron transfer from the quinol pool to a small electron donor and/or then to $\mathrm{N}_{2} \mathrm{OR}$.

\section{Model Compounds of $\mathrm{N}_{2} \mathrm{OR}$ "CuZ" center}

As mentioned in Section 4.2, the catalytic site of $\mathrm{N}_{2} \mathrm{OR}$ is a tetranuclear copper site coordinated by nitrogen atoms from seven different histidine residues bridged by a $\mu_{4}$-sulfido ligand, arranged in a distorted tetrahedron [78]. The two known highly catalytic competent forms of $\mathrm{N}_{2} \mathrm{OR}$ are the fully reduced state of $\mathrm{CuZ}^{*}(4 \mathrm{Cu} 1 \mathrm{~S})\left(\left[4 \mathrm{Cu}^{1+}\right], \mathrm{S}=0\right)$ and the $\mathrm{CuZ}^{0}$ intermediate species $\left(\left[1 \mathrm{Cu}^{2+}: 3 \mathrm{Cu}^{1+}\right], \mathrm{S}=1 / 2\right)[89,108,110,117,119,121]$. Structural, spectroscopic and computational studies propose that $\mathrm{N}_{2} \mathrm{O}$ binds to the $\mathrm{Cu}_{\mathrm{I}}-\mathrm{Cu}_{\mathrm{IV}}$ edge and a protonated lysine stabilizes the $\mathrm{N}_{2} \mathrm{O}$ bound intermediate [77, 102, 106, 107, 117]. The $\mathrm{CuZ} *(4 \mathrm{Cu} 1 \mathrm{~S})$ $\left(\left[1 \mathrm{Cu}^{2+}: 3 \mathrm{Cu}^{1+}\right], \mathrm{S}=1 / 2\right)$, also named "resting" state, can be converted to the active $\mathrm{CuZ}^{*}(4 \mathrm{Cu} 1 \mathrm{~S})\left[4 \mathrm{Cu}^{1+}\right]$ oxidation state, by a slow activation using reduced viologens $[92,96$, $98,99,102,103,107]$.

Such a unique structural motif involving different relevant redox states associated to four copper atoms bridged by a single sulfur atom contributes to the complexity of obtaining $\mathrm{N}_{2} \mathrm{OR}$ "CuZ" center synthetic models that could indeed help to explain some of the properties presented by this metal center. Multicopper complexes using more than one sulfur atom are more common, however do not reproduce neither the $\mathrm{CuZ} *(4 \mathrm{Cu} 1 \mathrm{~S})$ nor $\mathrm{CuZ}(4 \mathrm{Cu} 2 \mathrm{~S})$ centers [134-136]. Nevertheless, Tolman et al. reported a mixed valent trinuclear copper-disulfide cluster that could reduce $\mathrm{N}_{2} \mathrm{O}$ to $\mathrm{N}_{2}$ and proposed, using DFT studies, that $\mathrm{N}_{2} \mathrm{O}$ binds in a $\mu$ 1,1-bridging mode between the two copper atoms through the $\mathrm{O}$ atom [137]. This model 
represents an alternative mechanism to the $\mu-1,3$ binding mode of $\mathrm{N}_{2} \mathrm{O}$ proposed to occur at $\mathrm{N}_{2} \mathrm{OR}$ “CuZ” center [138].

\subsection{Trinuclear-sulfide copper complexes, [3Cu1S]}

Relevant model compounds with $\left[\mathrm{Cu}_{3} \mathrm{~S}_{1}\right]$ stoichiometry have been proposed by Murray, Hillhouse and Mankad [139-141]. Hillhouse and co-workers proposed the formation of a $\{(\operatorname{IPr}) \mathrm{CuI}\}_{3}\left(\mu_{3}-\mathrm{S}\right)^{1+}$ complex, (IPr = 1,3-bis(2,6-diisopropylphenyl)imidazol-2-ylidene), Nheterocyclic carbene that was prepared adding sequential (IPr) $\mathrm{Cu}^{1+}$ centers on a sulfido ligand [139]. This complex is a $\mathrm{Cu}^{1+}{ }_{3}\left(\mu_{3}-\mathrm{S}\right) \mathrm{L}_{3}$ cluster, with a flattened pyramidal core due to the absence of other bridging ligands. Mankad et al., synthesized and characterized a $\left[\left(\mu_{2^{-}}\right.\right.$ dcpm $\left.)_{3} \mathrm{Cu}_{3}\left(\mu_{3}-\mathrm{S}\right)\right]^{1+}$ cluster (dcpm= bis(dicyclohexylphosphino)methane) that was able to bind iodide, a proposed inhibitor of $\mathrm{N}_{2} \mathrm{OR}[79,140]$. Murray obtained a $\mathrm{Cu}_{3} \mathrm{~L}$ compound, where $\mathrm{L}$ is a cyclophane ligand that reacted with elemental sulfur to generate $\mathrm{Cu}_{3}\left(\mu_{3}-\mathrm{S}\right) \mathrm{L}$ [141]. This complex was the first sulfur-bridged copper cluster wherein each copper is held in a N-rich environment and it is coordinatively unsaturated. This model represented a considerable advance compared to the models that used phosphine ligands to stabilize the $\mathrm{Cu}_{3}\left(\mu_{3}-\mathrm{S}\right)$ clusters.

\subsection{Tetranuclear-sulfide copper complexes, [4Cu1S]}

The goal to obtain model compounds more structurally faithful to the $\mathrm{N}_{2} \mathrm{OR}$ " $\mathrm{CuZ}$ " center, lead to the synthesis of complexes with the $\left[\mathrm{Cu}_{4} \mathrm{~S}\right]$ stoichiometry. Interestingly the synthesis of such a cluster was first reported by Yam and co-workers, in 1993, before the publishing of the first $\mathrm{N}_{2} \mathrm{OR}$ crystallographic structure [142]. The cluster $\left[(\mathrm{dppm})_{4} \mathrm{Cu}_{4}\left(\mu_{4}-\mathrm{S}\right)\right]^{2+}$ (dppm=bis(diphenylphosphino)methane) reported by Yam is a tetranuclear $\mathrm{Cu}^{1+} \mathrm{dppm}$ complex that has a distorted square pyramid structure with the sulfur atom at the apex projecting above the $\mathrm{Cu}_{4}$ plane. Some similarities $\left[(\mathrm{dppm})_{4} \mathrm{Cu}_{4}\left(\mu_{4}-\mathrm{S}\right)\right]^{2+} / \mathrm{N}_{2} \mathrm{OR}$ catalytic center are observed, both clusters have a $C_{2}$ symmetry with two short $(\sim 2.9 / 2.6 \AA)$ and two long $\mathrm{Cu}-\mathrm{Cu}$ distances $(\sim 3.1 / 3.4 \AA)$ (Figure $5 \AA)$. The geometry of the sulfur atom is $\tau_{4}=0.59$ for the $\left[(\mathrm{dppm})_{4} \mathrm{Cu}_{4}\left(\mu_{4}-\right.\right.$ $\mathrm{S})]^{2+}$ and $\tau_{4}=0.66$ for the $\mathrm{N}_{2} \mathrm{OR} \mathrm{CuZ} *(4 \mathrm{Cu} 1 \mathrm{~S})$ center [143]. These complexes are luminescent and can be obtained using different synthetic approaches [144, 145]. However, the cluster is inactive towards $\mathrm{N}_{2} \mathrm{O}$. Mankad et al. also assembled a $\left[\mathrm{Cu}^{1+}{ }_{4}\left(\mu_{4}-\mathrm{S}\right)\right]$ cluster using phosphorous ligands (diphosphine), the $\left[\left(\mu_{2}-\mathrm{dppa}\right)_{4} \mathrm{Cu}_{4}\left(\mu_{4}-\mathrm{S}\right)\right]^{2+}$ cluster (dppa=bis(diphenylphosphino)amine) [140]. The supporting diphosphine ligands allow the tuning of the reduction potentials of the cluster and simultaneously provide hydrogen-bond donors to the second coordination 
sphere (Figure 5B). The cluster does not react with $\mathrm{N}_{2} \mathrm{O}$ but it is able to bind iodide and azide. Binding of iodide results in the loss of nuclearity forming different trinuclear copper clusters. This is not observed for $\mathrm{N}_{2} \mathrm{OR}$ " $\mathrm{CuZ}$ " center and the authors proposed that the polypeptide chain is probably involved in the stabilization of the center nuclearity in the enzyme.

An important major breakthrough was obtained by Johnson and Mankad with the report of a $(\mathrm{NCN})_{4} \mathrm{Cu}_{4}\left(\mu_{4}-\mathrm{S}\right) \quad\left(\mathrm{NCN}=\left(2,4,6-\mathrm{Me}_{3} \mathrm{C}_{6} \mathrm{H}_{2} \mathrm{~N}\right)_{2} \mathrm{CH}\right)$ complex, a cluster supported only by nitrogen ligands (Figure 5C) [146]. The complex structure possesses near-perfect $C_{2 V}$ symmetry, with short $\mathrm{Cu}-\mathrm{Cu}$ distances of $2.4 \AA$ and long $\mathrm{Cu}-\mathrm{Cu}$ distances of $3.0 \AA$. The sulfur geometry is characterized by a $\tau_{4}$ of 0.76 . The formal oxidation state is $\left[2 \mathrm{Cu}^{+2}: 2 \mathrm{Cu}^{1+}\right]$ and the complex presented a visible absorption spectrum with a main band at $561 \mathrm{~nm}$ and a shoulder at $470 \mathrm{~nm}$, suggesting that the complex is a model for oxidized $\mathrm{CuZ}(4 \mathrm{Cu} 2 \mathrm{~S})$. The oxidized $\mathrm{CuZ}(4 \mathrm{Cu} 2 \mathrm{~S})$ is also a singlet ground state absorbing at $545 \mathrm{~nm}$, whereas the $\mathrm{CuZ} *(4 \mathrm{Cu} 1 \mathrm{~S})$ absorbs at $640 \mathrm{~nm}$ in the $\left[1 \mathrm{Cu}^{2+}: 3 \mathrm{Cu}^{1+}\right]$ state. The purified complex is EPR silent confirming its diamagnetic $(S=0)$ behavior in this oxidation state [147]. The same diamagnetic behavior is observed for the oxidized CuZ(4Cu2S) state of the "CuZ" center (Table 1). The complex can be electrochemically reduced reversibly to $\left[1 \mathrm{Cu}^{2+}: 3 \mathrm{Cu}^{1+}\right]$ and irreversibly to the fully reduced state. Although in the structure of the $(\mathrm{NCN})_{4} \mathrm{Cu}_{4}\left(\mu_{4}-\mathrm{S}\right)$ complex there is no sulfur atom bridging two coppers, the combined spectroscopic and electrochemical data obtained seems to be more similar to the $\mathrm{CuZ}(4 \mathrm{Cu} 2 \mathrm{~S})$ center of $\mathrm{N}_{2} \mathrm{OR}$ than to $\mathrm{CuZ} *(4 \mathrm{Cu} 1 \mathrm{~S})$.

The reduction of $(\mathrm{NCN})_{4} \mathrm{Cu}_{4}\left(\mu_{4}-\mathrm{S}\right)$ was chemically obtained using [K(18-crown-6) $\left.)_{2}\right][\mathrm{Fp}]$ $\left(\mathrm{Fp}=\mathrm{gFeCp}(\mathrm{CO})_{2}\right)$, producing a cluster with a formal oxidation state of $\left[1 \mathrm{Cu}^{+2}: 3 \mathrm{Cu}^{1+}\right]$ (Figure 5D). The complex crystalized as two symmetrically independent tetranuclear copper anions [147]. Upon reduction, differences between $\mathrm{Cu}$ long and $\mathrm{Cu}$ short distances are smaller, and the complex acquires a more squared shape. For the fully reduced $\left[(\mathrm{dppm})_{4} \mathrm{Cu}_{4}\left(\mu_{4}-\mathrm{S}\right)\right]^{2+}$ cluster the tetranuclear copper core, $\mathrm{Cu}_{4}$, is even more similar to a square-based pyramid. However, the geometry of the sulfur atom measured by the $\tau_{4}$ parameter for this complex $\left(\tau_{4}=0.90\right)$ does not show the same pattern throughout reduction. The reduction of the complex caused a small shift in the visible absorption spectra from 561 to $566 \mathrm{~nm}$. TD-DFT calculations show that the visible absorption band observed from charge transfer bands from the four copper centers to the $\mathrm{S}$ resemble a delocalized $\mathrm{Cu} 3 d$ to $\mathrm{Cu}-\mathrm{S} \sigma^{*}$ transition. X-band and Q-band EPR studies indicated a $\mathrm{S}=1 / 2$ complex with $\mathrm{Cu}$ hyperfine splitting, and values of $\mathrm{A} \perp=3.4 \mathrm{mT}$ and $\mathrm{A} \|=0.5 \mathrm{mT}$. EPR data for the reduced complex suggests a mixture of two resonance contributors: a delocalized $4 \mathrm{Cu}^{1.25}: \mathrm{S}^{2-}$ mixed-valent species, and a $4 \mathrm{Cu}^{1+}: \mathrm{S}^{1-}$ sulfur-radical species. The sulfur 
atom has the highest spin density among the atoms of the complex [147]. The reduced complex has the ability to react with $\mathrm{N}_{2} \mathrm{O}$ to form $\mathrm{N}_{2}$ and it is proposed to be a structural and functional model of $\mathrm{CuZ} *(4 \mathrm{Cu} 1 \mathrm{~S})$. According to Johnson and Mankad, the oxidized and reduced forms of this complex together with the fully reduced complex proposed by Yam et al. completes a synthetic cycle for $\mathrm{N}_{2} \mathrm{O}$ reduction.

In Table 1 are summarized some of the spectroscopic and structural properties of the different $\mathrm{Cu}_{4}\left(\mu_{4}-\mathrm{S}\right)$ clusters described above, as well as the ones of $\mathrm{CuZ}(4 \mathrm{Cu} 2 \mathrm{~S})$ and $\mathrm{CuZ} *(4 \mathrm{Cu} 1 \mathrm{~S})$ forms of $\mathrm{N}_{2} \mathrm{OR}$ " $\mathrm{CuZ}$ ” center.

The fact that three catalytic relevant $\mathrm{Cu}_{4} \mathrm{~S}$ oxidation states have been modulated is important although not always this corresponds to the same functional properties regarding catalysis observed for $\mathrm{N}_{2} \mathrm{OR}$ "CuZ" center. Comparing the structural and functional data obtained for complexes modelling the "CuZ" center with the center itself, we can observe that the "CuZ" center functional behavior does not depend only on the oxidation state of its atoms, or the presence/absence of the bridging ligands, or the spin state. The functionality of "CuZ" center relays also on the second coordination sphere and on the H-bonding stabilizing effect, as well as in the presence of the polypeptide chain that contributes to maintain not only the tetranuclearity of the center but also to stabilize the three oxidation states observed during the catalytic cycle of the enzyme (Figure 4).

\subsection{Copper complexes reactivity towards $\mathrm{N}_{2} \mathrm{O}$}

The tetranuclearity of copper complexes is not a requirement for reactivity towards $\mathrm{N}_{2} \mathrm{O}$. Several $\left[\mathrm{Cu}_{2} \mathrm{~S}\right]$ complexes with the minimum reactive motif for $\mathrm{N}_{2} \mathrm{O}$, mimicking the $\mathrm{Cu}_{\mathrm{I}}-\mathrm{Cu}_{\mathrm{IV}}$ edge, have been synthesized and showed to have activity towards $\mathrm{N}_{2} \mathrm{O}$. Torelli and co-workers proposed a new dissymmetric mixed-valent dicopper(II,I) $\left[2 \cdot\left(\mathrm{H}_{2} \mathrm{O}\right)(\mathrm{OTf})\right]^{1+}(\mathrm{OTf}=$ trifluoromethanesulfonate ion) containing two different exchangeable ligands (triflate and water) that was able to reduce $\mathrm{N}_{2} \mathrm{O}$ producing $\mathrm{N}_{2}$ resulting on a $\left[\mathrm{Cu}_{2}(\mu-\mathrm{SR})(\mu-\mathrm{OH})\right]$ core [148]. The $\mathrm{N}_{2} \mathrm{O}$ molecule is proposed to displace the labile $\mathrm{H}_{2} \mathrm{O}$ ligand and the releasing of the $\mathrm{N}_{2}$ molecule originates an oxidized $\mathrm{Cu}^{2+} \mathrm{Cu}^{3+}(\mu-O)$ intermediate. This intermediate can react with the original copper complex to form a $\left[3 \cdot(\mu-\mathrm{OH})(\mathrm{OTf})_{2}\right]$ complex (Figure 6A). The complex reactivity resembles the one of $\mathrm{CuZ} *(4 \mathrm{Cu} 1 \mathrm{~S})$ in the $\left[4 \mathrm{Cu}^{1+}\right]$ oxidation state that contains an open coordination site at the $\mathrm{Cu}_{\mathrm{I}}-\mathrm{Cu}_{\mathrm{IV}}$ edge available to bind the substrate (Figure 4). A previous inactive related complex featuring a symmetric and saturated coordination sphere was 
not able to react with $\mathrm{N}_{2} \mathrm{O}$ underling the importance of the labile ligands in the $\mathrm{N}_{2} \mathrm{O}$ reduction [149].

Mankad et al. tested the reactivity towards $\mathrm{N}_{2} \mathrm{O}$ and $\mathrm{CO}$ of a synthesized $\mathrm{Cu}^{1+}{ }_{2}(\mu-\mathrm{S})$ complex obtained by Hillhouse and co-workers, $\left\{\left(\operatorname{IPr}^{*}\right) \mathrm{Cu}\right\}_{2}(\mu-\mathrm{S})\left(\operatorname{IPr}^{*}=1,3-b i s(2,6-(\right.$ diphenylmethyl)4-methylphenyl)imidazol-2-ylidene), and observed that the reaction of this complex with $\mathrm{N}_{2} \mathrm{O}$ resulted in a mixture of six compounds, in which the major product of the reaction was $\left[\left(\mathrm{IPr}^{*}\right) \mathrm{Cu}\right]_{2}\left(\mu-\mathrm{SO}_{4}\right)$, with a minor product being $[(\operatorname{IPr} *) \mathrm{Cu}]_{2}(\mu-\mathrm{O})[150,151]$. The results obtained suggest the importance of the tetranuclearity of the "CuZ" center to protect the $\mathrm{S}^{2-}$ ligand from oxidation or expulsion.

Tolman et al. proposed the first copper complex that was able to reduce $\mathrm{N}_{2} \mathrm{O}$ producing dinitrogen gas. The complex is a trinuclear copper-disulfide cluster assigned as a mixed valent $\left[1 \mathrm{Cu}^{2+}: 2 \mathrm{Cu}^{1+}\right]$ complex bridged by a $\mathrm{S}^{2-}$ ligand that is in equilibrium with a binuclear copper cluster that is probably the reactive species towards $\mathrm{N}_{2} \mathrm{O}$ (Figure 6B) [137]. The mechanism proposed for $\mathrm{N}_{2} \mathrm{O}$ binding is through a $\mu-\mathrm{O}$ bridge between the two copper ions.

The reduced $(\mathrm{NCN})_{4} \mathrm{Cu}_{4}\left(\mu_{4}-\mathrm{S}\right)$ cluster, described above in Section 5.2, is also able to react with $\mathrm{N}_{2} \mathrm{O}$ at low temperatures. However, the mechanism involved is not yet elucidated, one hypothesis is that two molecules of the reduced $(\mathrm{NCN})_{4} \mathrm{Cu}_{4}\left(\mu_{4}-\mathrm{S}\right)$ cluster are involved in the $\mathrm{N}_{2} \mathrm{O}$ reduction, one cluster acting as an activator and the other as a reductant (Figure 6C) [147]. This is the first $\left[\mathrm{Cu}_{4} \mathrm{~S}\right]$ cluster with the ability to reduce $\mathrm{N}_{2} \mathrm{O}$ and can be considered a functional $\mathrm{CuZ} *(4 \mathrm{Cu} 1 \mathrm{~S})$ mimic.

\section{Concluding Remarks}

$\mathrm{N}_{2} \mathrm{O}$ is a powerful greenhouse gas with a growing importance on global warming. Controlling $\mathrm{N}_{2} \mathrm{O}$ emissions, particularly its growing release, may be the next step to avoid a major problem in the future. $\mathrm{N}_{2} \mathrm{OR}$ is the enzyme responsible for the reduction of $\mathrm{N}_{2} \mathrm{O}$ to $\mathrm{N}_{2}$ although two other enzymes (nitrogenase and a multicopper oxidase) can also catalyze this reaction. Studies characterizing the structure and catalytic cycle of $\mathrm{N}_{2} \mathrm{OR}$ represent an important contribution from the scientific community for the design of successful strategies to control atmospheric $\mathrm{N}_{2} \mathrm{O}$ released by anthropogenic and natural sources.

The large activation barrier for nitrous oxide reduction to generate $\mathrm{N}_{2}$ is probably responsible for the high complexity associated with the "CuZ" center of $\mathrm{N}_{2} \mathrm{OR}$. This is a quite unparallel cluster in Nature, representing a considerable challenge not only for biochemists but also to inorganic chemists in an effort to mimic its structure. We have now a reasonable knowledge of 
$\mathrm{N}_{2} \mathrm{OR}$, an enzyme that can be isolated in two forms concerning the catalytic "CuZ" cluster, $\mathrm{CuZ} *(4 \mathrm{Cu} 1 \mathrm{~S})$ and $\mathrm{CuZ}(4 \mathrm{Cu} 2 \mathrm{~S})$. These two forms have different catalytic and spectroscopic properties and recently an intermediate species, $\mathrm{CuZ}^{0}$, was identified as an important catalytic competent species on the catalytic cycle of $\mathrm{N}_{2} \mathrm{OR}$.

The purification of the enzyme resulting in two different forms of its catalytic "CuZ" center, $\mathrm{CuZ}(4 \mathrm{Cu} 2 \mathrm{~S})$ and $\mathrm{CuZ} *(4 \mathrm{Cu} 1 \mathrm{~S})$, raises several questions, such as (i) what active form of "CuZ" center is responsible for $\mathrm{N}_{2} \mathrm{O}$ reduction in vivo, and (ii) whether there are any still unknown partners involved in catalysis that can facilitate the enzyme activation, or (iii) even whether it is possible to interconvert both forms of "CuZ" center in vivo. Another relevant question not yet solved is how the $\mathrm{pH}$ affects the enzyme production and activity and therefore if it is possible to use $\mathrm{pH}$ soil changes to control $\mathrm{N}_{2} \mathrm{O}$ emissions.

Different model compounds that intend to mimic different forms of the catalytic cycle of "CuZ" center are now available and a complete cycle for $\mathrm{N}_{2} \mathrm{O}$ reduction using only synthetic compounds was achieved. The model compounds available in the literature represent not only an important way to understand the catalytic and spectroscopic properties of $\mathrm{N}_{2} \mathrm{OR}$ but also represent a huge potential for a future use of these model compounds in $\mathrm{N}_{2} \mathrm{O}$ mitigation. However, further studies on the model compounds stability and reversibility between different oxidation and catalytic states are important to obtain deeper insights on the $\mathrm{N}_{2} \mathrm{OR}$ catalytic site and $\mathrm{N}_{2} \mathrm{O}$ reduction.

\section{Acknowledgements}

We would like to thank I. Cabrito, S. Dell'Acqua, C. Carreira and E. Johnston, for their contribution for the work presented here. We would also like to acknowledge the contributions of C. Cambillau, E. Solomon and O. Einsle for the fruitful discussions and collaborative work during the past years.

The authors would like to thank Fundação para a Ciência e Tecnologia (FCT) for the financial support provided (PTDC/BIA-PRO/098882/2008 to SRP and PTDC/BBB-BQB/0129/2014 to IM and MSPC). This work was supported by the Associate Laboratory for Green ChemistryLAQV and Unidade de Ciências Biomoleculares Aplicadas-UCIBIO, which is financed by national funds from FCT/MCTES (UID/QUI/50006/2019 and UID/Multi/04378/2019, respectively). 


\section{Author contribution}

SRP planned and wrote the manuscript, MSCP contributed to the writing of the manuscript, and IM critically revised the manuscript. 


\section{References}

[1] IPCC, Climate Change 2014: Mitigation of Climate Change, in: O. Edenhofer, R. PichsMadruga, Y. Sokona (Eds.) Contribution of Working Group III to the Fifth Assessment Report of the Intergovernmental Panel on Climate Change., Cambridge University Press, Cambridge, 2014.

[2] W.C. Trogler, J. Chem. Educ., 72 (1995) 973.

[3] IPCC, Climate Change 2007: The Physical Science Basis, in: S. Solomon, D. Qin, M. Manning (Eds.) Contribution of Working Group I to the Fourth Assessment Report of the Intergovernmental Panel on Climate Change., Cambridge University Press, Cambridge, 2007. [4] A.R. Ravishankara, J.S. Daniel, R.W. Portmann, Science, 326 (2009) 123-125.

[5] A.R. Mosier, Biol. Fertil. Soils, 27 (1998) 221-229.

[6] M.J. Prather, Science, 279 (1998) 1339-1341.

[7] D.J. Wuebbles, Science, 326 (2009) 56-57.

[8] W. Ye, L. Bian, C. Wang, R. Zhu, X. Zheng, M. Ding, J. Environ. Sci., 47 (2016) 193-200. [9] K. Lassey, M. Harvey, Water \& Atmosphere, 15 (2007) 10-11.

[10] L. Pauling, Proc. Natl. Acad. Sci. U.S.A., 18 (1932) 498-499.

[11] G.A. Vaughan, P.B. Rupert, G.L. Hillhouse, J. Am. Chem. Soc., 109 (1987) 5538-5539.

[12] A. Miyamoto, S. Baba, M. Mori, Y. Murakami, J. Physic. Chem., 85 (1981) 3117-3122.

[13] R. Zeng, M. Feller, Y. Ben-David, D. Milstein, J. Am. Chem. Soc., 139 (2017) 5720-5723.

[14] A. Dandekar, M.A. Vannice, Appl. Catal., B, 22 (1999) 179-200.

[15] R.W. Portmann, J.S. Daniel, A.R. Ravishankara, Philos. Trans. R. Soc. Lond. B Biol. Sci., 367 (2012) 1256-1264.

[16] D.J. Lary, J. Geophys. Res., 102 (1997) 21515-21526.

[17] E.E. Gard, M.J. Kleeman, D.S. Gross, L.S. Hughes, J.O. Allen, B.D. Morrical, D.P. Fergenson, T. Dienes, E.G. M, R.J. Johnson, G.R. Cass, K.A. Prather, Science, 279 (1998) 1184-1187.

[18] N. Gruber, J.N. Galloway, Nature, 451 (2008) 293-296.

[19] J.N. Galloway, F.J. Dentener, D.G. Capone, E.W. Boyer, R.W. Howarth, S.P. Seitzinger, G.P. Asner, C.C. Cleveland, P.A. Green, E.A. Holland, D.M. Karl, A.F. Michaels, J.H. Porter, A.R. Townsend, C.J. Vöosmarty, Biogeochemistry, 70 (2004) 153-226.

[20] T.J. Griffis, Z. Chen, J.M. Baker, J.D. Wood, D.B. Millet, X. Lee, R.T. Venterea, P.A. Turner, Proc. Natl. Acad. Sci. U.S.A., 114 (2017) 12081-12085. 
[21] I. Shcherbak, N. Millar, G.P. Robertson, Proc. Natl. Acad. Sci. U.S.A., 111 (2014) 91999204.

[22] W.H. Schlesinger, Proc. Natl. Acad. Sci. U.S.A., 106 (2009) 203-208.

[23] L.Y. Stein, Y.L. Yung, Annu. Rev. Earth and Planet. Sci., 31 (2003) 329-356.

[24] G. Braker, R. Conrad, Adv. Appl. Microbiol., 75 (2011) 33-70.

[25] S. Hallin, L. Philippot, F.E. Loffler, R.A. Sanford, C.M. Jones, Trends Microbiol., 26 (2018) 43-55.

[26] L.Y. Stein, M.G. Klotz, Biochem. Soc. Trans., 39 (2011) 1826-1831.

[27] R. Yu, M.J. Kampschreur, M.C. van Loosdrecht, K. Chandran, Environ. Sci. Technol., 44 (2010) 1313-1319.

[28] P. Wunderlin, J. Mohn, A. Joss, L. Emmenegger, H. Siegrist, Water Res., 46 (2012) 1027 1037.

[29] R.A. Sanford, D.D. Wagner, Q. Wu, J.C. Chee-Sanford, S.H. Thomas, C. Cruz-Garcia, G. Rodriguez, A. Massol-Deya, K.K. Krishnani, K.M. Ritalahti, S. Nissen, K.T. Konstantinidis, F.E. Loffler, Proc. Natl. Acad. Sci. U.S.A., 109 (2012) 19709-19714.

[30] S. Yoon, S. Nissen, D. Park, R.A. Sanford, F.E. Loffler, Appl. Environ. Microbiol., 82 (2016) 3793-3800.

[31] J.R. Onley, S. Ahsan, R.A. Sanford, F.E. Loffler, Appl. Environ. Microbiol., (2017).

[32] J.N. Galloway, A.R. Townsend, J.W. Erisman, M. Bekunda, Z. Cai, J.R. Freney, L.A. Martinelli, S.P. Seitzinger, M.A. Sutton, Science, 320 (2008) 889-892.

[33] H. Shoun, S. Fushinobu, L. Jiang, S.W. Kim, T. Wakagi, Philos. Trans. R. Soc. Lond. B Biol. Sci., 367 (2012) 1186-1194.

[34] K. Maeda, A. Spor, V. Edel-Hermann, C. Heraud, M.C. Breuil, F. Bizouard, S. Toyoda, N. Yoshida, C. Steinberg, L. Philippot, Sci. Rep., 5 (2015) 9697.

[35] S.A. Higgins, A. Welsh, L.H. Orellana, K.T. Konstantinidis, J.C. Chee-Sanford, R.A. Sanford, C.W. Schadt, F.E. Loffler, Appl. Environ. Microbiol., 82 (2016) 2919-2928.

[36] D.R. Graf, C.M. Jones, S. Hallin, PLoS One, 9 (2014) el14118.

[37] L. Philippot, J. Andert, C.M. Jones, D. Bru, S. Hallin, Global Change Biol., 17 (2010) 1497-1504.

[38] M.K. Firestone, R.B. Firestone, J.M. Tiedje, Science, 208 (1980) 749-751.

[39] B. Liu, P.T. Mørkved, A. Frostegård, L.R. Bakken, FEMS Microbiol. Ecol., 72 (2010) 407-417. 
[40] R.N. Van Den Heuvel, S.E. Bakker, M.S.M. Jetten, M.M. Hefting, Geobiology, 9 (2011) 294-300.

[41] L. Bergaust, Y. Mao, L.R. Bakken, A. Frostegård, Appl. Environ. Microbiol., 76 (2010) 6387-6396.

[42] P. Lycus, M.J. Soriano-Laguna, M. Kjos, D.J. Richardson, A.J. Gates, D.A. Milligan, A. Frostegard, L. Bergaust, L.R. Bakken, Proc. Natl. Acad. Sci. U.S.A., 115 (2018) 11820-11825. [43] L. Bergaust, R.J. van Spanning, A. Frostegard, L.R. Bakken, Microbiology, 158 (2012) 826-834

[44] J. Hassan, Z. Qu, L.L. Bergaust, L.R. Bakken, PLoS Comput Biol, 12 (2016) e1004621.

[45] R. Wan, Y. Chen, X. Zheng, Y. Su, M. Li, Environ. Sci. Technol., 50 (2016) 9915-9922.

[46] R. Wan, L. Wang, Y. Chen, X. Zheng, Y. Su, X. Tao, Sci. Total Environ., 643 (2018) 1074-1083.

[47] J.H. Park, H.S. Shin, I.S. Lee, J.H. Bae, Environ. Technol., 23 (2002) 53-65.

[48] Y. Liu, L. Peng, H.H. Ngo, W. Guo, D. Wang, Y. Pan, J. Sun, B.J. Ni, Environ. Sci. Technol., 50 (2016) 9407-9415.

[49] H. Lu, H. Huang, W. Yang, H.R. Mackey, S.K. Khanal, D. Wu, G.H. Chen, Water Res., 133 (2018) 165-172.

[50] B.M. Hoffman, D. Lukoyanov, Z.Y. Yang, D.R. Dean, L.C. Seefeldt, Chem. Rev., 114 (2014) 4041-4062.

[51] J.M. Rivera-Ortiz, R.H. Burris, J. Bacteriol., 123 (1975) 537-545.

[52] J. Liang, R.H. Burris, Biochemistry, 27 (1988) 6726-6732.

[53] J. Liang, R.H. Burris, J. Bacteriol., 171 (1989) 3176-3180.

[54] J. Christiansen, L.C. Seefeldt, D.R. Dean, J. Biol. Chem., 275 (2000) 36104-36107.

[55] M.S. Coyne, D.D. Focht, Appl. Environ. Microbiol., 53 (1987) 1168-1170.

[56] A.T. Fernandes, J.M. Damas, S. Todorovic, R. Huber, M.C. Baratto, R. Pogni, C.M. Soares, L.O. Martins, FEBS J., 277 (2010) 3176-3189.

[57] W.G. Zumft, P.M. Kroneck, Adv. Microb. Physiol., 52 (2007) 107-227.

[58] S.R. Pauleta, S. Dell'Acqua, I. Moura, Coord. Chem. Rev., 257 (2013) 332-349.

[59] K. Jones, Nitrogen, in: J.C. Bailar, H.J. Emelöus, R. Nyholm, A.F. Trottman-Dickenson (Eds.) Comprehensive Inorganic Chemistry, Pergamon Press, Oxford, 1975, pp. 147-388.

[60] W.G. Zumft, Microbiol. Molec. Biol. Rev., 61 (1997) 533-616.

[61] C. Carreira, S.R. Pauleta, I. Moura, J. Inorg. Biochem., 177 (2017) 423-434. 
[62] C.M. Jones, A. Welsh, I.N. Throback, P. Dorsch, L.R. Bakken, S. Hallin, FEMS Microbiol. Ecol., 76 (2011) 541-552.

[63] D. Mania, K. Heylen, R.J. van Spanning, A. Frostegard, Environ. Microbiol., 16 (2014) 3196-3210.

[64] D. Mania, K. Heylen, R.J. van Spanning, A. Frostegard, Environ. Microbiol., 18 (2016) 2937-2950.

[65] J. Simon, O. Einsle, P.M. Kroneck, W.G. Zumft, FEBS Lett., 569 (2004) 7-12.

[66] S. Teraguchi, T.C. Hollocher, J. Biol. Chem., 264 (1989) 1972-1979.

[67] C.S. Zhang, T.C. Hollocher, A.F. Kolodziej, W.H. Orme-Johnson, J. Biol. Chem., 266 (1991) 2199-2202.

[68] C. Zhang, A.M. Jones, T.C. Hollocher, Biochem. Biophys. Res. Commun., 187 (1992) $135-139$

[69] C.S. Zhang, T.C. Hollocher, Biochim. Biophys. Acta, 1142 (1993) 253-261.

[70] M. Luckmann, D. Mania, M. Kern, L.R. Bakken, A. Frostegard, J. Simon, Microbiology, 160 (2014) 1749-1759.

[71] L.H. Orellana, R.L. Rodriguez, S. Higgins, J.C. Chee-Sanford, R.A. Sanford, K.M. Ritalahti, F.E. Loffler, K.T. Konstantinidis, MBio, 5 (2014) e01193-01114.

[72] I. Verbaendert, S. Hoefman, P. Boeckx, N. Boon, P. De Vos, FEMS Microbiol. Ecol., 89 (2014) 162-180.

[73] K. Chourey, S. Nissen, T. Vishnivetskaya, M. Shah, S. Pfiffner, R.L. Hettich, F.E. Loffler, Proteomics, 13 (2013) 2921-2930.

[74] C. Carreira, O. Mestre, R.F. Nunes, I. Moura, S.R. Pauleta, PeerJ, 6 (2018) e5603.

[75] M. Kern, J. Simon, Biochim. Biophys. Acta, 1787 (2009) 646-656.

[76] S. Hein, S. Witt, J. Simon, Environ. Microbiol., 19 (2017) 4913-4925.

[77] K. Brown, M. Tegoni, M. Prudêncio, A.S. Pereira, S. Besson, J.J.G. Moura, I. Moura, C. Cambillau, Nat. Struct. Biol., 7 (2000) 191-195.

[78] K. Brown, K. Djinovic-Carugo, T. Haltia, I. Cabrito, M. Saraste, J.J.G. Moura, I. Moura, M. Tegoni, C. Cambillau, J. Biol. Chem., 275 (2000) 41133-41136.

[79] K. Paraskevopoulos, S.V. Antonyuk, R.G. Sawers, R.R. Eady, S.S. Hasnain, J. Mol. Biol., 362 (2006) 55-65.

[80] A. Pomowski, W.G. Zumft, P.M. Kroneck, O. Einsle, Nature, 477 (2011) 234-237.

[81] S. Dell'acqua, I. Moura, J.J. Moura, S.R. Pauleta, J. Biol. Inorg. Chem., 16 (2011) 12411254 
[82] T. Matsubara, H. Iwasaki, 71 (1972) 747-750.

[83] W.G. Zumft, T. Matsubara, FEBS Lett., 148 (1982) 107-112.

[84] J.R. Winkler, Curr. Opin. Chem. Biol., 4 (2000) 192-198.

[85] H. Beinert, Eur. J. Biochem., 245 (1997) 521-532.

[86] Suharti, M.J. Strampraad, I. Schroder, S. de Vries, Biochemistry, 40 (2001) 2632-2639.

[87] J.A. Farrar, F. Neese, P. Lappalainen, P.M.H. Kroneck, M. Saraste, W.G. Zumft, A.J. Thomson, J. Am. Chem. Soc., 118 (1996) 11501-11514.

[88] D.R. Gamelin, D.W. Randall, M.T. Hay, R.P. Houser, T.C. Mulder, G.W. Canters, S.d. Vries, W.B. Tolman, Y. Lu, E.I. Solomon, J. Am. Chem. Soc., 120 (1998) 5246-5263.

[89] C.L. Coyle, W.G. Zumft, P.M. Kroneck, H. Korner, W. Jakob, Eur. J. Biochem., 153 (1985) 459-467.

[90] P.M. Kroneck, W.A. Antholine, J. Riester, W.G. Zumft, FEBS Lett., 242 (1988) 70-74.

[91] W.E. Antholine, D.H. Kastrau, G.C. Steffens, G. Buse, W.G. Zumft, P.M. Kroneck, Eur. J. Biochem., 209 (1992) 875-881.

[92] T. Rasmussen, B.C. Berks, J.N. Butt, A.J. Thomson, Biochem. J., 364 (2002) 807-815.

[93] S. Dell'Acqua, S.R. Pauleta, P.M.P. de Sousa, E. Monzani, L. Casella, J.J.G. Moura, I. Moura, J. Biol. Inorg. Chem., 15 (2010) 967-976.

[94] S. Yoshikawa, A. Shimada, K. Shinzawa-Itoh, Met. Ions Life Sci., 15 (2015) 89-130.

[95] T. Tosha, Y. Shiro, IUBMB Life, 65 (2013) 217-226.

[96] M. Prudencio, A.S. Pereira, P. Tavares, S. Besson, I. Cabrito, K. Brown, B. Samyn, B. Devreese, J. Van Beeumen, F. Rusnak, G. Fauque, J.J. Moura, M. Tegoni, C. Cambillau, I. Moura, Biochemistry, 39 (2000) 3899-3907.

[97] P. Wunsch, H. Korner, F. Neese, R.J. van Spanning, P.M. Kroneck, W.G. Zumft, FEBS Lett., 579 (2005) 4605-4609.

[98] T. Rasmussen, B.C. Berks, J. Sanders-Loehr, D.M. Dooley, W.G. Zumft, A.J. Thomson, Biochemistry, 39 (2000) 12753-12756.

[99] J.A. Farrar, W.G. Zumft, A.J. Thomson, Proc. Natl. Acad. Sci. U.S.A., 95 (1998) 9891 9896.

[100] M.L. Alvarez, J. Ai, W. Zumft, J. Sanders-Loehr, D.M. Dooley, J. Am. Chem. Soc., 123 (2001) 576-587.

[101] L.K. Schneider, O. Einsle, Biochemistry, 55 (2016) 1433-1440.

[102] P. Chen, S. DeBeer George, I. Cabrito, W.E. Antholine, J.J. Moura, I. Moura, B. Hedman, K.O. Hodgson, E.I. Solomon, J. Am. Chem. Soc., 124 (2002) 744-745. 
[103] J.A. Farrar, A.J. Thomson, M.R. Cheesman, D.M. Dooley, W.G. Zumft, FEBS Lett., 294 (1991) 11-15.

[104] V.S. Oganesyan, T. Rasmussen, S. Fairhurst, A.J. Thomson, Dalton Trans., (2004) 9961002 .

[105] D.M. Dooley, M.A. McGuirl, A.C. Rosenzweig, J.A. Landin, R.A. Scott, W.G. Zumft, F. Devlin, P.J. Stephens, Inorg. Chem., 30 (1991) 3006-3011.

[106] P. Chen, I. Cabrito, J.J.G. Moura, I. Moura, E.I. Solomon, J. Am. Chem. Soc., 124 (2002) 10497-10507.

[107] P. Chen, S.I. Gorelsky, S. Ghosh, E.I. Solomon, Angew. Chem., 43 (2004) 4132-4140.

[108] S. Ghosh, S.I. Gorelsky, George, S. DeBeer, J.M. Chan, I. Cabrito, D.M. Dooley, J.J.G. Moura, I. Moura, E.I. Solomon, J. Am. Chem. Soc., 129 (2007) 3955-3965.

[109] E.I. Solomon, D.E. Heppner, E.M. Johnston, J.W. Ginsbach, J. Cirera, M. Qayyum, M.T. Kieber-Emmons, C.H. Kjaergaard, R.G. Hadt, L. Tian, Chem. Rev., 114 (2014) 3659-3853.

[110] E.M. Johnston, S. Dell'Acqua, S.R. Pauleta, I. Moura, E.I. Solomon, Chem. Sci., 6 (2015) $5670-5679$.

[111] S.G. Mayhew, Eur. J. Biochem., 85 (1978) 535-547.

[112] S. Dell'Acqua, S.R. Pauleta, J.J. Moura, I. Moura, Philos. Trans. R. Soc. Lond. B Biol. Sci., 367 (2012) 1204-1212.

[113] H. Körner, K. Frunzke, K. Döhler, W.G. Zumft, Arch. Microbiol., 148 (1987) 20-24.

[114] C.K. SooHoo, T.C. Hollocher, J. Biol. Chem., 266 (1991) 2203-2209.

[115] S. Ferretti, J.G. Grossmann, S.S. Hasnain, R.R. Eady, B.E. Smith, Eur. J. Biochem., 259 (1999) 651-659.

[116] S.R. Pauleta, C. Carreira, I. Moura, Insights into Nitrous Oxide Reductase, in: I. Moura, J.J.G. Moura, S.R. Pauleta, L. Maia (Eds.) Metalloenzymes in Denitrification: Applications and Environmental Impacts, RSC, 2017, pp. 141-169.

[117] S. Ghosh, S.I. Gorelsky, P. Chen, I. Cabrito, J.J.G. Moura, I. Moura, E.I. Solomon, J. Am. Chem. Soc., 125 (2003) 15708-15709.

[118] J.M. Chan, J. Bollinger, C.L. Grewell, D.M. Dooley, J. Am. Chem. Soc., 126 (2004) 3030-3031.

[119] E.M. Johnston, S. Dell'Acqua, S. Ramos, S.R. Pauleta, I. Moura, E.I. Solomon, J. Am. Chem. Soc., 136 (2014) 614-617.

[120] S. Dell'acqua, S.R. Pauleta, E. Monzani, A.S. Pereira, L. Casella, J.J. Moura, I. Moura, Biochemistry, 47 (2008) 10852-10862. 
[121] E.M. Johnston, C. Carreira, S. Dell'Acqua, S.G. Dey, S.R. Pauleta, I. Moura, E.I. Solomon, J. Am. Chem. Soc., 139 (2017) 4462-4476.

[122] M.Z. Ertem, C.J. Cramer, F. Himo, P.E. Siegbahn, J. Biol. Inorg. Chem., 17 (2012) $687-$ 698.

[123] B.C. Berks, D. Baratta, D.J. Richardson, S.J. Ferguson, Eur. J. Biochem., 212 (1993) 467476.

[124] M. Itoh, K. Matsuura, T. Satoh, FEBS Lett., 251 (1989) 104-108.

[125] D.J. Richardson, L.C. Bell, A.G. McEwan, J.B. Jackson, S.J. Ferguson, Eur. J. Biochem., 199 (1991) 677-683.

[126] J.W.B. Moir, S.J. Ferguson, Microbiology, 140 (1994) 389-397.

[127] K. Fujita, J.M. Chan, J.a. Bollinger, M.L. Alvarez, D.M. Dooley, J. Inorg. Biochem., 101 (2007) 1836-1844.

[128] T. Rasmussen, T. Brittain, B.C. Berks, N.J. Watmough, A.J. Thomson, Dalton Trans., (2005) 3501-3506.

[129] F.C. Boogerd, H.W. van Verseveld, A.H. Stouthamer, FEBS Lett., 113 (1980) 279-284.

[130] J.M. Borrero-de Acuna, M. Rohde, J. Wissing, L. Jansch, M. Schobert, G. Molinari, K.N. Timmis, M. Jahn, D. Jahn, J. Bacteriol., 198 (2016) 1401-1413.

[131] J.M. Borrero-de Acuna, K.N. Timmis, M. Jahn, D. Jahn, Microb. Biotechnol., 10 (2017) $1523-1534$.

[132] P. Wunsch, W.G. Zumft, J. Bacteriol., 187 (2005) 1992-2001.

[133] L. Zhang, C. Trncik, S.L.A. Andrade, O. Einsle, Biochim. Biophys. Acta, 1858 (2017) 95-102.

[134] J.T. York, I. Bar-Nahum, W.B. Tolman, Inorg. Chem., 46 (2007) 8105-8107.

[135] Y. Lee, A.A. Sarjeant, K.D. Karlin, Chem. Commun. (Camb), (2006) 621-623.

[136] C.B. Khadka, B.K. Najafabadi, M. Hesari, M.S. Workentin, J.F. Corrigan, Inorg. Chem., 52 (2013) 6798-6805.

[137] I. Bar-Nahum, A.K. Gupta, S.M. Huber, M.Z. Ertem, C.J. Cramer, W.B. Tolman, J. Am. Chem. Soc., 131 (2009) 2812-2814.

[138] S.I. Gorelsky, S. Ghosh, E.I. Solomon, J. Am. Chem. Soc., 128 (2006) 278-290.

[139] J.J. Zhai, M.D. Hopkins, G.L. Hillhouse, Organometallics, 34 (2015) 4637-4640.

[140] B.J. Johnson, S.V. Lindeman, N.P. Mankad, Inorg. Chem., 53 (2014) 10611-10619.

[141] G.N. Di Francesco, A. Gaillard, I. Ghiviriga, K.A. Abboud, L.J. Murray, Inorg. Chem., 53 (2014) 4647-4654. 
[142] V.W.W. Yam, W.K. Lee, T.F. Lai, J. Chem. Soc. Chem. Commun., (1993) 1571-1573.

[143] L. Yang, D.R. Powell, R.P. Houser, Dalton Transactions, (2007) 955-964.

[144] R.N. Yang, Y.A. Sun, Y.M. Hou, X.Y. Hu, D.M. Jin, Inorg. Chim. Acta, 304 (2000) 1-6.

[145] C.R. Wang, K.K.W. Lo, W.K.M. Fung, V.W.W. Yam, Chem. Phys. Lett., 296 (1998) $505-514$

[146] B.J. Johnson, W.E. Antholine, S.V. Lindeman, N.P. Mankad, Chem. Commun. (Camb), 51 (2015) 11860-11863.

[147] B.J. Johnson, W.E. Antholine, S.V. Lindeman, M.J. Graham, N.P. Mankad, J. Am. Chem. Soc., (2016).

[148] C. Esmieu, M. Orio, S. Torelli, L. Le Pape, J. Pecaut, C. Lebrun, S. Menage, Chem. Sci., 5 (2014) 4774-4784.

[149] S. Torelli, M. Orio, J. Pecaut, H. Jamet, L. Le Pape, P. Menage, Angew. Chem., 49 (2010) $8249-8252$

[150] J. Zhai, A.S. Filatov, G.L. Hillhouse, M.D. Hopkins, Chem. Sci., 7 (2016) 589-595.

[151] S. Bagherzadeh, N.P. Mankad, Chem. Commun. (Camb), 54 (2018) 1097-1100.

[152] K. Yamaguchi, A. Kawamura, H. Ogawa, S. Suzuki, J. Biochem., 134 (2003) 853-858.

[153] S.W. Snyder, T.C. Hollocher, J. Biol. Chem., 262 (1987) 6515-6525.

[154] M. Giles, N. Morley, E.M. Baggs, T.J. Daniell, Front. Microbiol., 3 (2012) 407.

[155] J. Simon, M.G. Klotz, Biochim. Biophys. Acta, 1827 (2013) 114-135.

[156] B.J. Johnson, N.P. Mankad, Model Compounds of Copper-Containing Enzymes Involved in Bacterial Denitrification, in: J.J.G.M. I. Moura, S. R Pauleta, L. B Maia (Ed.) Metalloenzymes in Denitrification: Applications and Environmental Impacts, RSC, London, 2017, pp. 225 - 251. 
Table 1 - Summary of "CuZ" center properties from $\mathrm{N}_{2} \mathrm{OR}$ and from model compounds that mimic the "CuZ" center. The different oxidation states, the geometry index for four-coordinate centers $\left(\tau_{4}\right)$, spectroscopic data and activity towards $\mathrm{N}_{2} \mathrm{O}$ properties.

\begin{tabular}{|c|c|c|c|c|c|c|c|}
\hline Cluster & $\begin{array}{c}\begin{array}{c}\text { Oxidation state } \\
\text { (CuI - CuIv ligand) }\end{array} \\
\end{array}$ & $\tau_{\mathbf{4}}(\mathbf{S})$ & Visible absorption & Spin state & EPR & $\begin{array}{c}\text { Activi } \\
\text { ty } \\
\left(\mathrm{N}_{2} \mathrm{O}\right) \\
\end{array}$ & Ref. \\
\hline $\mathrm{CuZ} *(4 \mathrm{Cu} 1 \mathrm{~S})$ & $\begin{array}{c}{\left[1 \mathrm{Cu}^{2+}: 3 \mathrm{Cu}^{1+}: \mathrm{S}: \mathrm{OH}\right]} \\
\left(\mathrm{Bridging} \mathrm{OH}^{-}\right)\end{array}$ & 0.66 & $\begin{array}{c}640 \mathrm{~nm} \\
\left(\sim 3.5 \mathrm{mM}^{-1} \mathrm{~cm}^{-1}\right)^{\mathrm{a}}\end{array}$ & $\mathrm{S}=1 / 2$ & $\begin{array}{l}\mathrm{g}_{\|}=2.160, \mathrm{~g}_{\perp}=2.040 \\
\mathrm{~A}_{\|}=6.1 \mathrm{mT} / \mathrm{A}_{\|}=2.4 \mathrm{mT}^{\mathrm{b}}\end{array}$ & No & $\begin{array}{c}{[92,96,98,99,103} \\
106,107]\end{array}$ \\
\hline $\begin{array}{l}\text { Fully reduced } \\
\mathrm{CuZ} *(4 \mathrm{Cu} 1 \mathrm{~S})\end{array}$ & $\begin{array}{l}{\left[4 \mathrm{Cu}^{1+}: \mathrm{S}\right]} \\
(\text { Empty) }\end{array}$ & - & No bands & $\mathrm{S}=0$ & Silent & Yes & $\begin{array}{c}{[89,108,110,117,} \\
119]\end{array}$ \\
\hline $\mathrm{CuZ}^{0}(4 \mathrm{Cu} 1 \mathrm{~S})$ & $\begin{array}{c}{\left[1 \mathrm{Cu}^{2+}: 3 \mathrm{Cu}^{1+}: \mathrm{S}: \mathrm{OH}\right]} \\
\left(\mathrm{Cu}_{\mathrm{IV}}-\mathrm{OH}^{-}\right)\end{array}$ & - & $\begin{array}{c}680 \mathrm{~nm} \\
\left(\sim 2.0 \mathrm{mM}^{-1} \mathrm{~cm}^{-1}\right)^{\mathrm{a}}\end{array}$ & $\mathrm{S}=1 / 2$ & $\begin{array}{l}\mathrm{g}_{\|}=2.177, \mathrm{~g}_{\perp}=2.05 \\
\mathrm{~A} \|=4.2 \mathrm{mT}^{\mathrm{c}}\end{array}$ & Yes & {$[93,121]$} \\
\hline $\begin{array}{l}\text { Oxidized } \\
\mathrm{CuZ}(4 \mathrm{Cu} 2 \mathrm{~S})\end{array}$ & $\begin{array}{l}{\left[2 \mathrm{Cu}^{2+}: 2 \mathrm{Cu}^{1+}: 2 \mathrm{~S}\right]} \\
\quad\left(\text { Bridging } \mathrm{S}^{2-}\right)\end{array}$ & 0.71 & $\begin{array}{c}545 \mathrm{~nm} \\
\left(\sim 5.0 \mathrm{mM}^{-1} \mathrm{~cm}^{-1}\right)^{\mathrm{a}}\end{array}$ & $\mathrm{S}=0$ & Silent & No & {$[89,92,99,110]$} \\
\hline $\begin{array}{l}\text { Reduced } \\
\mathrm{CuZ}(4 \mathrm{Cu} 2 \mathrm{~S})\end{array}$ & $\begin{array}{c}{\left[1 \mathrm{Cu}^{2+}: 3 \mathrm{Cu}^{1+}: 2 \mathrm{~S}\right]} \\
\left(\text { Bridging } \mathrm{SH}^{-}\right)\end{array}$ & N.D. & $\begin{array}{c}670 \mathrm{~nm} \\
\left(\sim 3.0-4.4 \mathrm{mM}^{-1} \mathrm{~cm}^{-1}\right)^{\mathrm{a}} \\
\end{array}$ & $\mathrm{S}=1 / 2$ & $\begin{array}{l}\mathrm{g}_{\|}=2.150, \mathrm{~g}_{\perp}=2.035 \\
\mathrm{~A}_{\|}=5.6 \mathrm{mT}^{\mathrm{d}}\end{array}$ & Yes & $\begin{array}{c}{[89,92,99,102,110,} \\
119,152,153]\end{array}$ \\
\hline$\left[(\mathrm{dppm})_{4} \mathrm{Cu}_{4}\left(\mu_{4}-\mathrm{S}\right)\right]^{2+}$ & {$\left[4 \mathrm{Cu}^{1+}\right]$} & 0.59 & No bands & - & - & No & {$[142]$} \\
\hline$\left[\left(\mu_{2}-\mathrm{dppa}\right)_{4} \mathrm{Cu}_{4}\left(\mu_{4}-\mathrm{S}\right)\right]^{2+}$ & {$\left[4 \mathrm{Cu}^{1+}\right]$} & 0.64 & No bands & - & - & No & {$[140]$} \\
\hline$(\mathrm{NCN})_{4} \mathrm{Cu}_{4}\left(\mu_{4}-\mathrm{S}\right)$ & {$\left[2 \mathrm{Cu}^{2+}: 2 \mathrm{Cu}^{1+}\right]$} & 0.76 & $\begin{array}{c}561 \mathrm{~nm} \\
\left(\sim 14.0 \mathrm{mM}^{-1} \mathrm{~cm}^{-1}\right)\end{array}$ & $\mathrm{S}=0$ & Silent & No & {$[146,147]$} \\
\hline $\begin{array}{l}\text { Reduced } \\
(\mathrm{NCN})_{4} \mathrm{Cu}_{4}\left(\mu_{4}-\mathrm{S}\right)\end{array}$ & {$\left[1 \mathrm{Cu}^{2+}: 3 \mathrm{Cu}^{1+}\right]$} & 0.90 & $\begin{array}{c}566 \mathrm{~nm} \\
\left(\sim 8.6 \mathrm{mM}^{-1} \mathrm{~cm}^{-1}\right)\end{array}$ & $\mathrm{S}=1 / 2$ & $\begin{array}{l}\mathrm{g}_{\perp}=2.090, \mathrm{~g}_{\|}=2.043 \\
\mathrm{~A}_{\perp}=3.4 \mathrm{mT} \\
\mathrm{A}_{\|}=0.53 \mathrm{mT}\end{array}$ & Yes & {$[147]$} \\
\hline
\end{tabular}

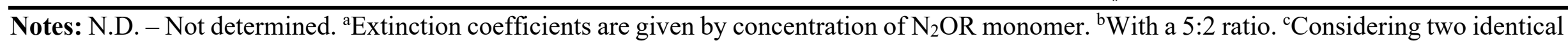
hyperfine coupling constants. ${ }^{\mathrm{d} C o n s i d e r i n g}$ three identical hyperfine coupling constants. 


\section{Schemes}

$\dot{0}^{-}=N^{+}=\ddot{O}: \longleftrightarrow \quad: N \equiv N^{+}-\ddot{O}_{:}^{-}$

Scheme 1 - Representation of the resonance structures of $\mathrm{N}_{2} \mathrm{O}$.

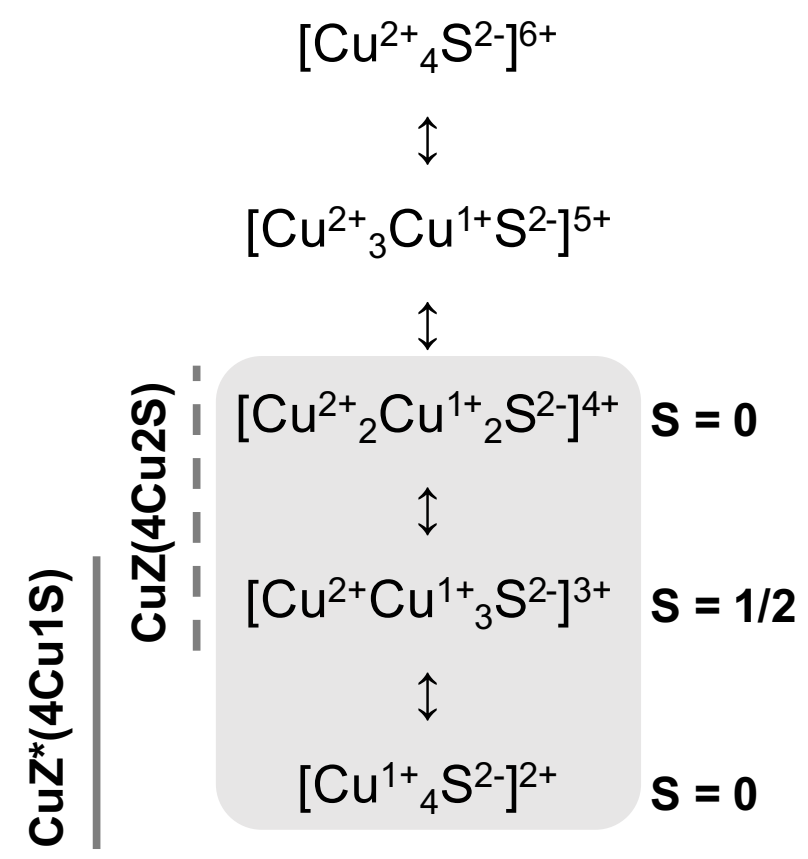

Scheme 2 - Possible oxidation states of "CuZ" core center. Shaded in grey are the oxidation states that have been observed and characterized for $\mathrm{CuZ} *(4 \mathrm{Cu} 1 \mathrm{~S})$ and $\mathrm{CuZ}(4 \mathrm{Cu} 2 \mathrm{~S})$. The spin state of the "CuZ" center in the three different forms is presented. 


\section{Figure Legends}

Figure 1 - Nitrogen biogeochemical cycle, highlighting the pathways that contribute to the release of nitrous oxide to the atmosphere. The different pathways that compose the cycle are identified by an arrow of a different color: denitrification in blue, nitrification in orange, nitrogen fixation in yellow, anammox in grey and dissimilatory nitrate reduction to ammonium (DNRA) in green. In black in the incorporation of ammonium into organic N-compounds catalyzed by glutamate synthase, glutamate dehydrogenase and glutamine synthetase. The enzyme that catalyzes each step are written above the corresponding arrow. The arrows in violet are the step at which nitrous oxide can be released to the atmosphere. Scheme adapted from $[154]$

Figure 2 - Clade I and Clade II $\mathrm{N}_{2} \mathrm{OR}$ gene organization and proposed electron transfer pathway from the quinol pool to $\mathrm{N}_{2} \mathrm{OR}$. In panel (A) it is represented, on the left, the nos $Z$ gene cluster organization of Clade $\mathrm{I}_{2} \mathrm{OR}$. On the right, it is represented the proposed electron transfer pathway from NosR to a small electron donor protein (ED) that then transfers the electron to $\mathrm{CuA}$ center of $\mathrm{N}_{2} \mathrm{OR}$. The possibility of a direct route from NosR to $\mathrm{N}_{2} \mathrm{OR}$ is also represented. In panel (B) it is represented, on the left, the nos $Z$ gene cluster organization of Clade II $\mathrm{N}_{2} \mathrm{OR}$. On the right, it is represented the proposed electron transfer pathway from membrane associated NosG/NosH, to NosC1, then to NosC2 and finally to $c$-type heme domain of $c$ NosZ of $W$. succinogenes. Figure was prepared based on [76, 155].

Legend: PA - pseudoazurin, Az - azurin, $\mathrm{C}$ - thioredoxin-like protein, $c$ - $c$-type cytochrome, $b$ - $b$-type cytochrome, FeS - Rieske-like iron-sulfur protein, $\mathrm{Fe} / \mathrm{S}$ - [4Fe-4S] cluster containing protein. The arrows in black correspond to hypothetical proteins, $d n r$ - dissimilative nitrate respiration regulator, tat - twin-arginine translocation. Genes are not represented to scale. The identified transcriptional units and promoter regions are denoted as arrows and dots, respectively, below the gene representation.

Figure 3 - Structure of Clade I N2OR and coordination of $\mathrm{CuA}$ and "CuZ" centers in the different forms of the enzyme. A) Structure of Pseudomonas stutzeri $\mathrm{N}_{2} \mathrm{OR}$ functional homodimer. The backbone of one monomer is represented with the identified secondary structure colored in violet with its transparent surface in light violet, and the other monomer is similarly represented in grey. $\mathrm{CuA}$ and "CuZ" centers are represented by spheres, in which the 
copper atoms are colored in blue. The distances between $\mathrm{CuA}$ and "CuZ" centers of the two monomers are represented. B) Coordination of CuA center in P. denitrificans $\mathrm{N}_{2} \mathrm{OR}$ on the left and in P. stutzeri $\mathrm{N}_{2} \mathrm{OR}$ on the right. C) Coordination of CuZ*(4Cu1S) in P. denitrificans $\mathrm{N}_{2} \mathrm{OR}$ on the left and of $\mathrm{CuZ}(4 \mathrm{Cu} 2 \mathrm{~S})$ in $P$. stutzeri $\mathrm{N}_{2} \mathrm{OR}$ on the right. Figures were prepared with Biovia Discovery Studio using PDB ID 1FWX for P. denitrificans and PDB ID 3SBP for $P$. stutzeri, and the following color scheme for the atoms: carbon in grey, $\mathrm{Cu}$ in dark blue, $\mathrm{N}$ in light blue; $\mathrm{S}$ in yellow, $\mathrm{O}$ in red.

Figure 4 - Catalytic cycle of $\mathrm{N}_{2} \mathrm{O}$ reduction by $\mathrm{N}_{2} \mathrm{OR}$ with " $\mathrm{CuZ}$ center" as $\mathrm{CuZ} *(4 \mathrm{Cu} 1 \mathrm{~S})$. The intermediate 1 and 3 have been isolated, while intermediate 2 remains to be characterized. Residues are numbered according to $P$. denitrificans $\mathrm{N}_{2} \mathrm{OR}$ mature primary sequence. Legend: ED - electron donor.

Figure 5 - X-ray structures of four tetranuclear-sulfide copper complexes of the type $\left[\mathrm{Cu}_{4} \mathrm{~S}\right]$. A - (dppm) $)_{4} \mathrm{Cu}_{4}\left(\mu_{4}-\mathrm{S}\right)\left(\mathrm{CCDC}\right.$ code 1290297) [142], B - $\left(\mu_{2}-\mathrm{dppa}\right)_{4} \mathrm{Cu}_{4}\left(\mu_{4}-\mathrm{S}\right)(\mathrm{CCDC}$ code, 988774) [140], C - $(\mathrm{NCN})_{4} \mathrm{Cu}_{4}\left(\mu_{4}-\mathrm{S}\right)$ (CCDC code 1405092147) [147], D - Reduced $(\mathrm{NCN})_{4} \mathrm{Cu}_{4}\left(\mu_{4}-\mathrm{S}\right)(\mathrm{CCDC}$ code 1521219) [147]. Figures were prepared with Biovia Discovery Studio using the following color scheme for the atoms: carbon in grey, $\mathrm{Cu}$ in dark blue, $\mathrm{N}$ in light blue; $\mathrm{S}$ in yellow, $\mathrm{O}$ in red and $\mathrm{P}$ in orange.

Figure 6 - Proposed reaction pathways for $\mathrm{N}_{2} \mathrm{O}$ reduction using model compounds. A Dinuclear copper thiolate complex; i) Structure of $\mathrm{Cu}_{2}\left[3 \cdot(\mu-\mathrm{OH})(\mathrm{OTf})_{2}\right](\mathrm{CCDC}$ code 948577$)$ [148]. B - Trinuclear copper-disulfide cluster; ii) Structure of the trinuclear copper-disulfide cluster (CCDC 95109) [137, 156]; C - Tetranuclear copper thiolate complex; iii) Structure of reduced $(\mathrm{NCN})_{4} \mathrm{Cu}_{4}\left(\mu_{4}-\mathrm{S}\right)(\mathrm{CCDC}$ code 1521219$)$ [147]. Figures were prepared with Biovia Discovery Studio using the following color scheme for the atoms: carbon in grey, $\mathrm{Cu}$ in dark blue, $\mathrm{N}$ in light blue; $\mathrm{S}$ in yellow, $\mathrm{O}$ in red and $\mathrm{P}$ in orange. The proposed reaction schemes with $\mathrm{N}_{2} \mathrm{O}$ were adapted from $[137,147,148,156]$. 


\section{Figures}

Figure 1

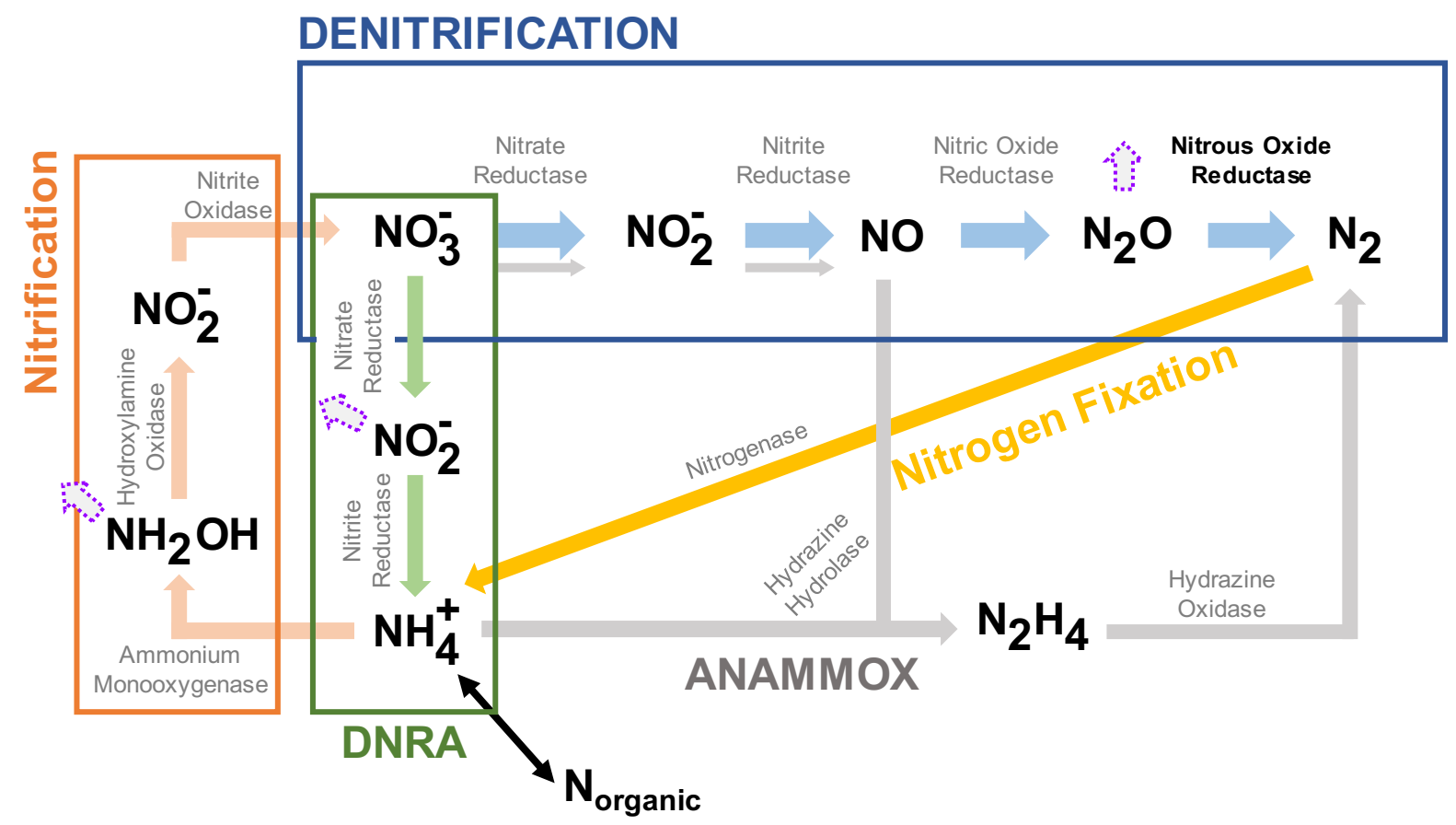


Figure 2

\section{(A) Clade I nosZ}

Paracoccus denitrificans PD1222

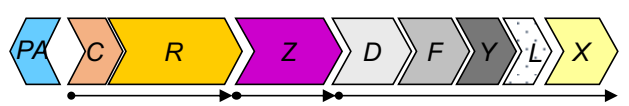

Pseudomonas stutzeri A1501

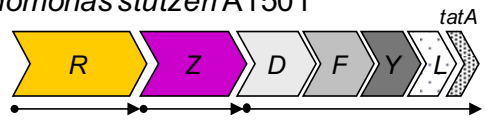

Marinobacter hydrocarbonoclasticus

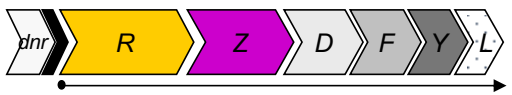

(B) Clade II nosZ

Anaeromyxobacter dehalogenans 2CP-1

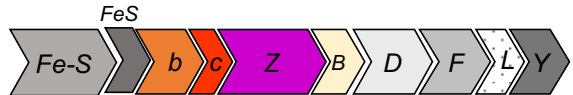

Dechloromonas aromatica RCB*

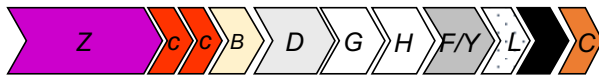

Wolinella succinogenesis DSM 1740

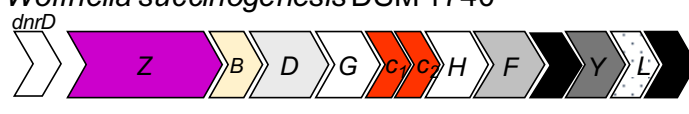

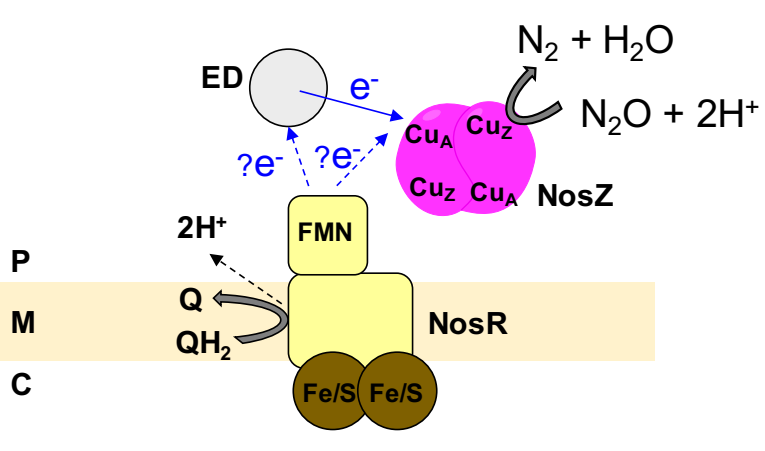

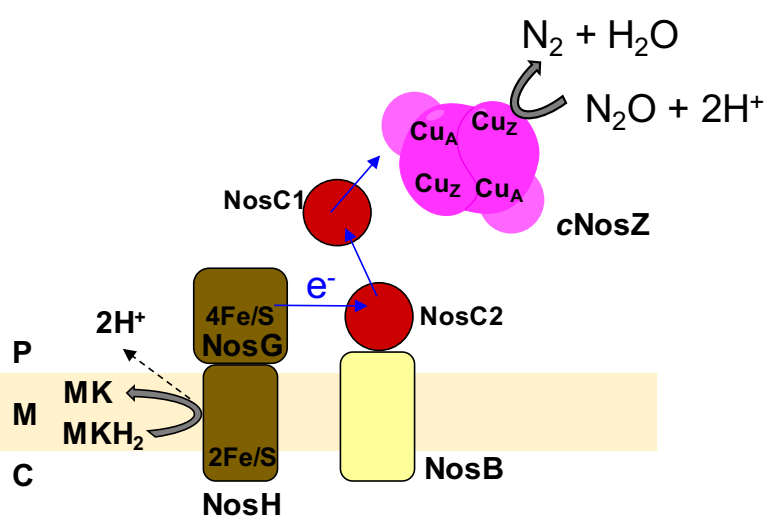


Figure 3

A)

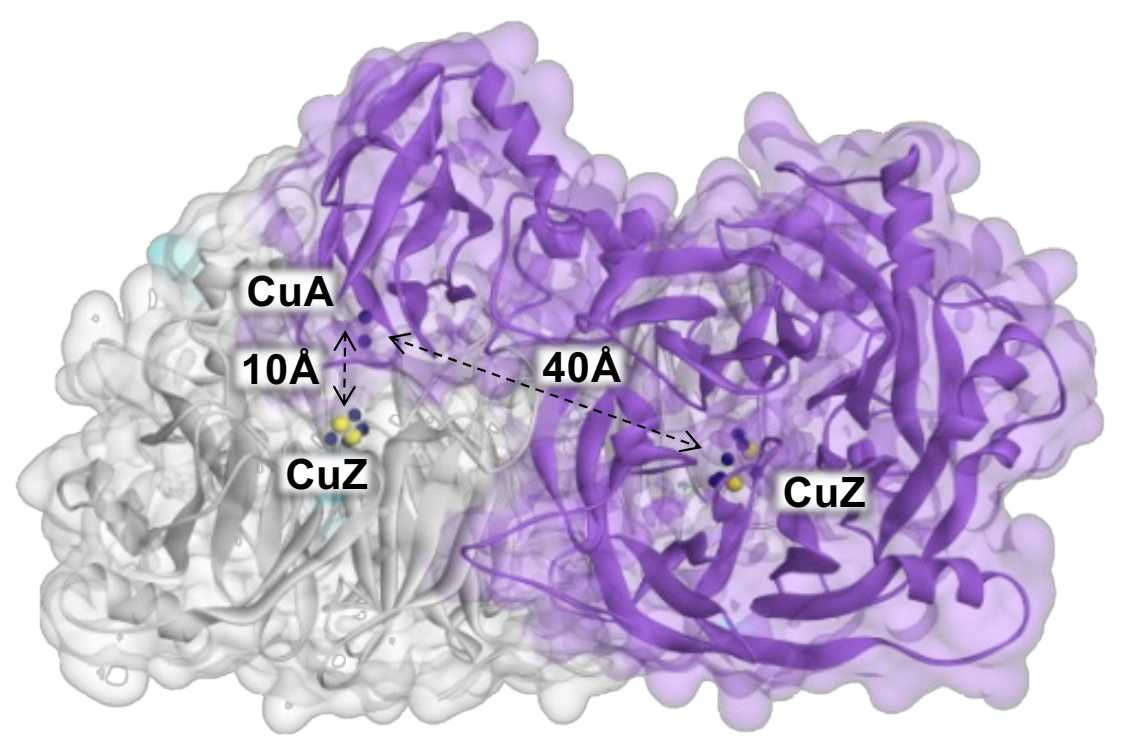

B) $\mathrm{CuA}$

CuA
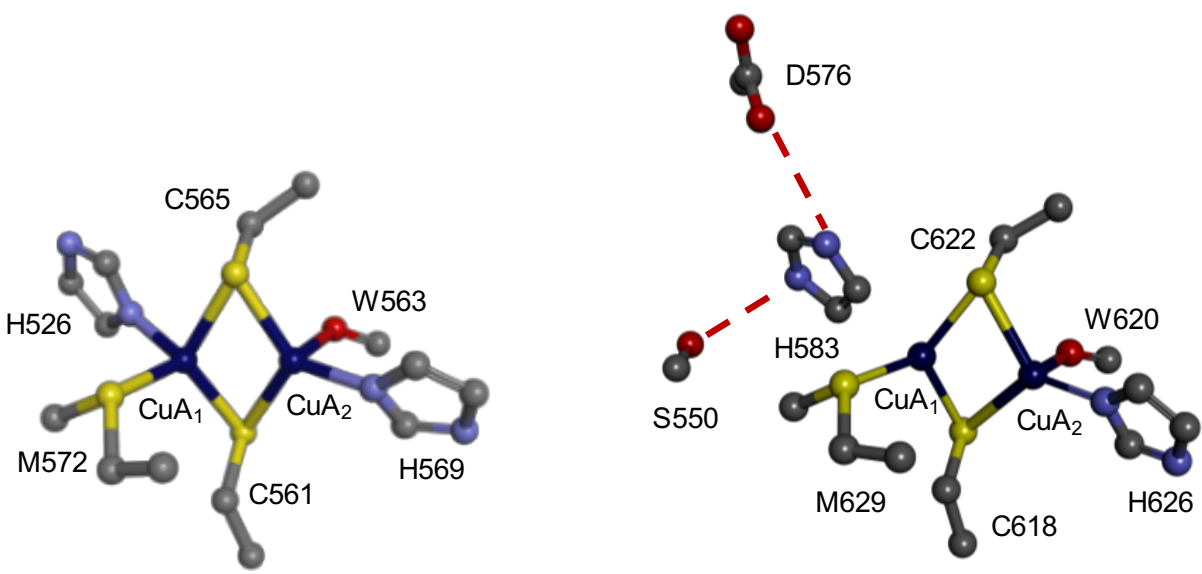

C) $\mathrm{CuZ}(4 \mathrm{Cu} 1 \mathrm{~S})$

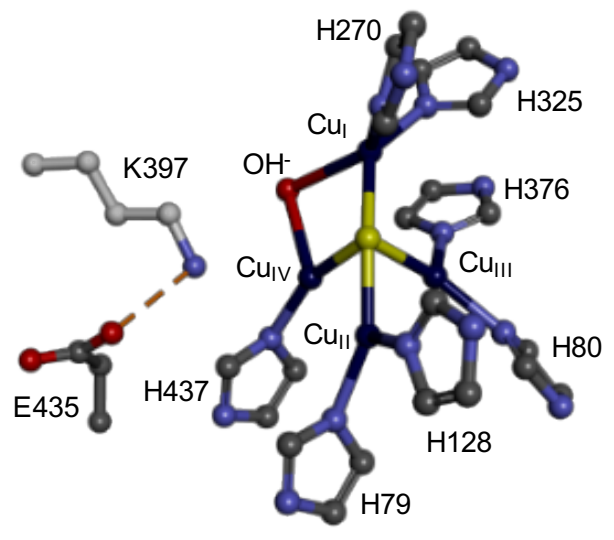

CuZ(4Cu2S)

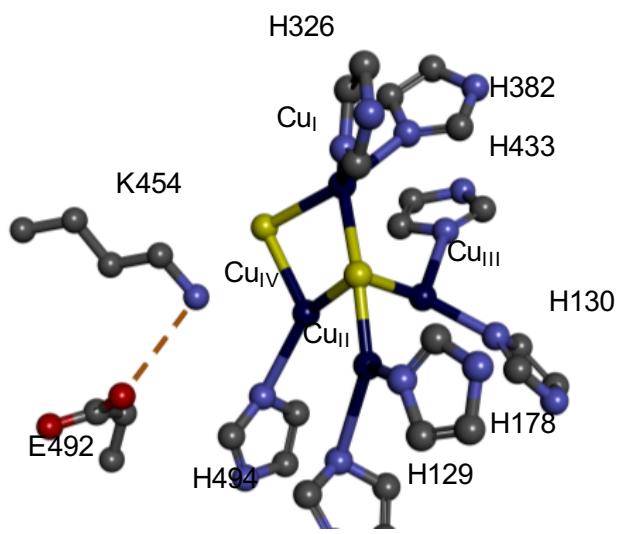


Figure 4

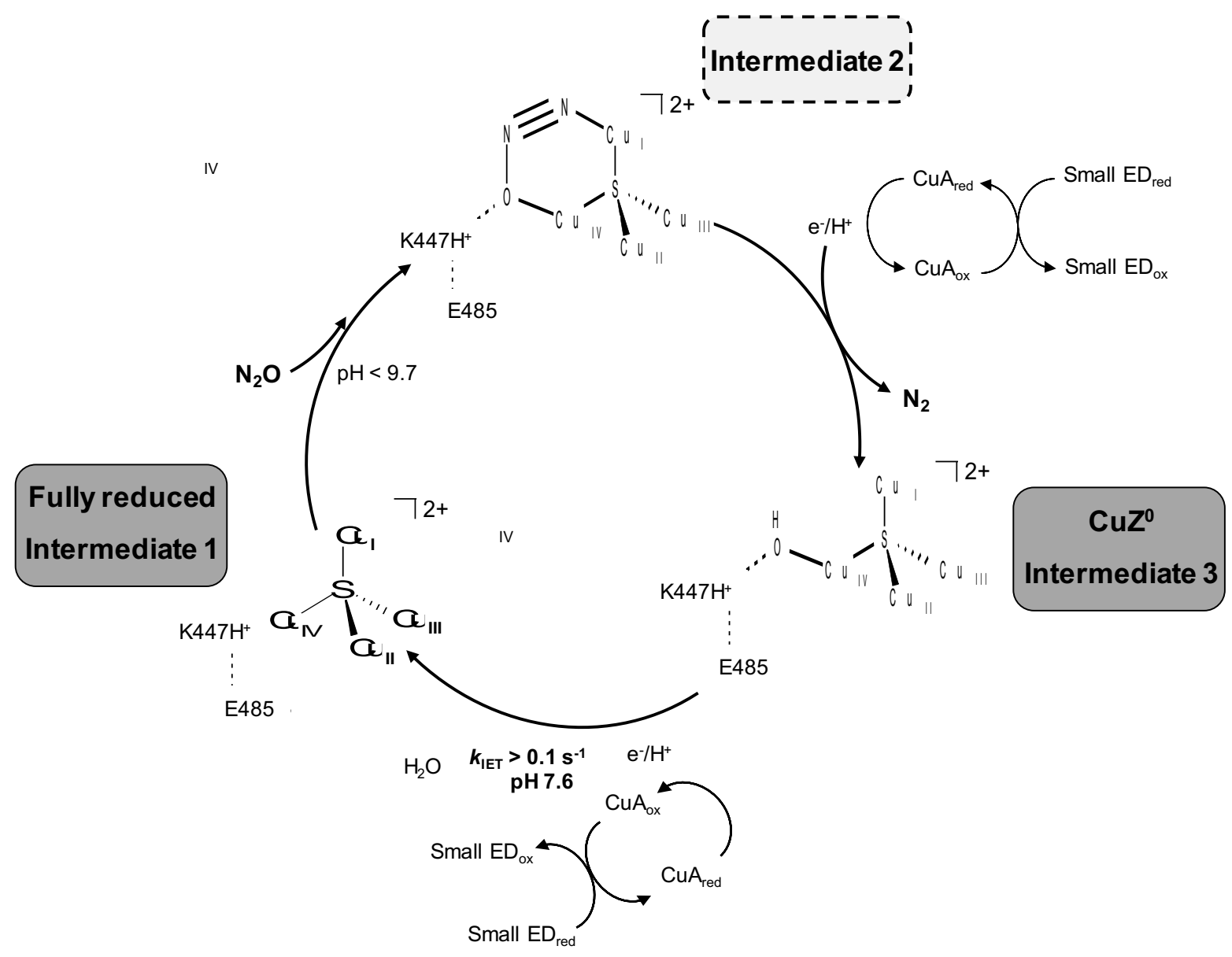


Figure 5

A

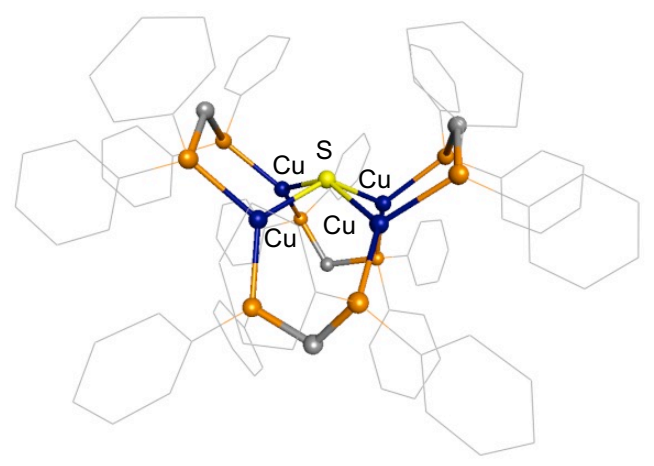

$(\mathrm{dppm})_{4} \mathrm{Cu}_{4}\left(\mu_{4}-\mathrm{S}\right)$

C

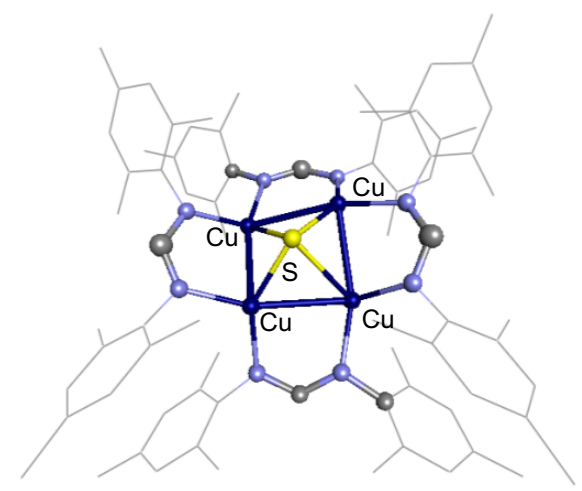

$(\mathrm{NCN})_{4} \mathrm{Cu}_{4}\left(\mu_{4}-\mathrm{S}\right)$
B

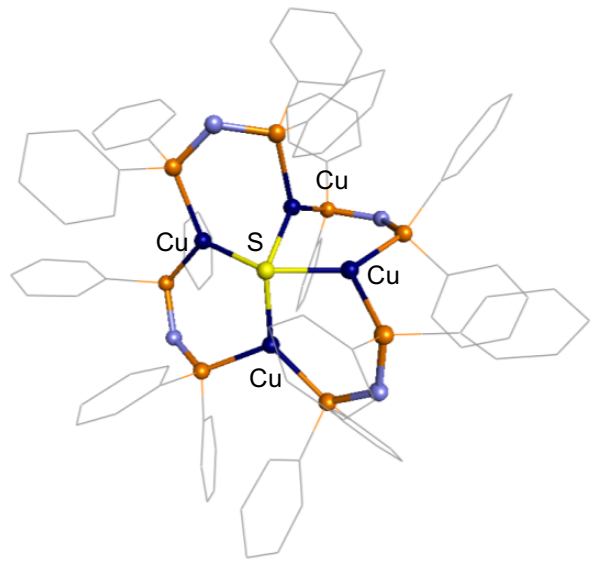

$\left(\mu_{2}-\text { dppa }\right)_{4} \mathrm{Cu}_{4}\left(\mu_{4}-\mathrm{S}\right)$

D

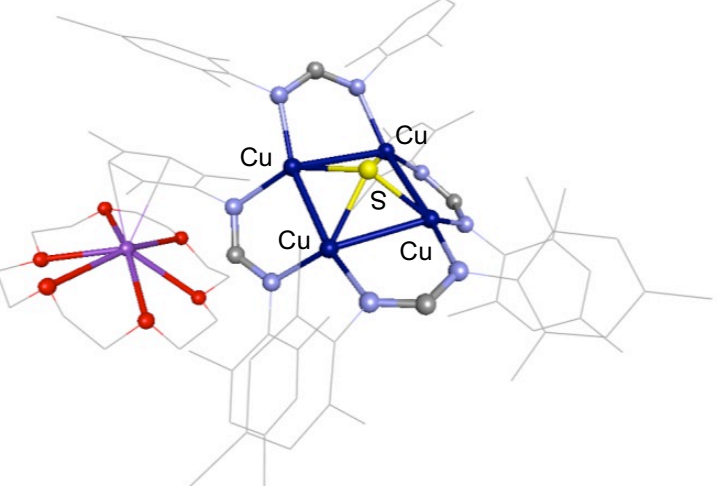

Reduced $(\mathrm{NCN})_{4} \mathrm{Cu}_{4}\left(\mu_{4}-\mathrm{S}\right)$ 
Figure 6

A

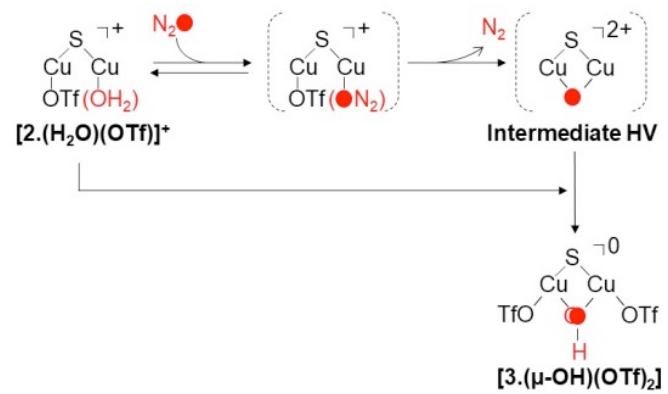

B

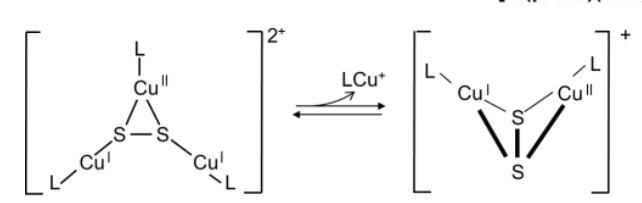

ii
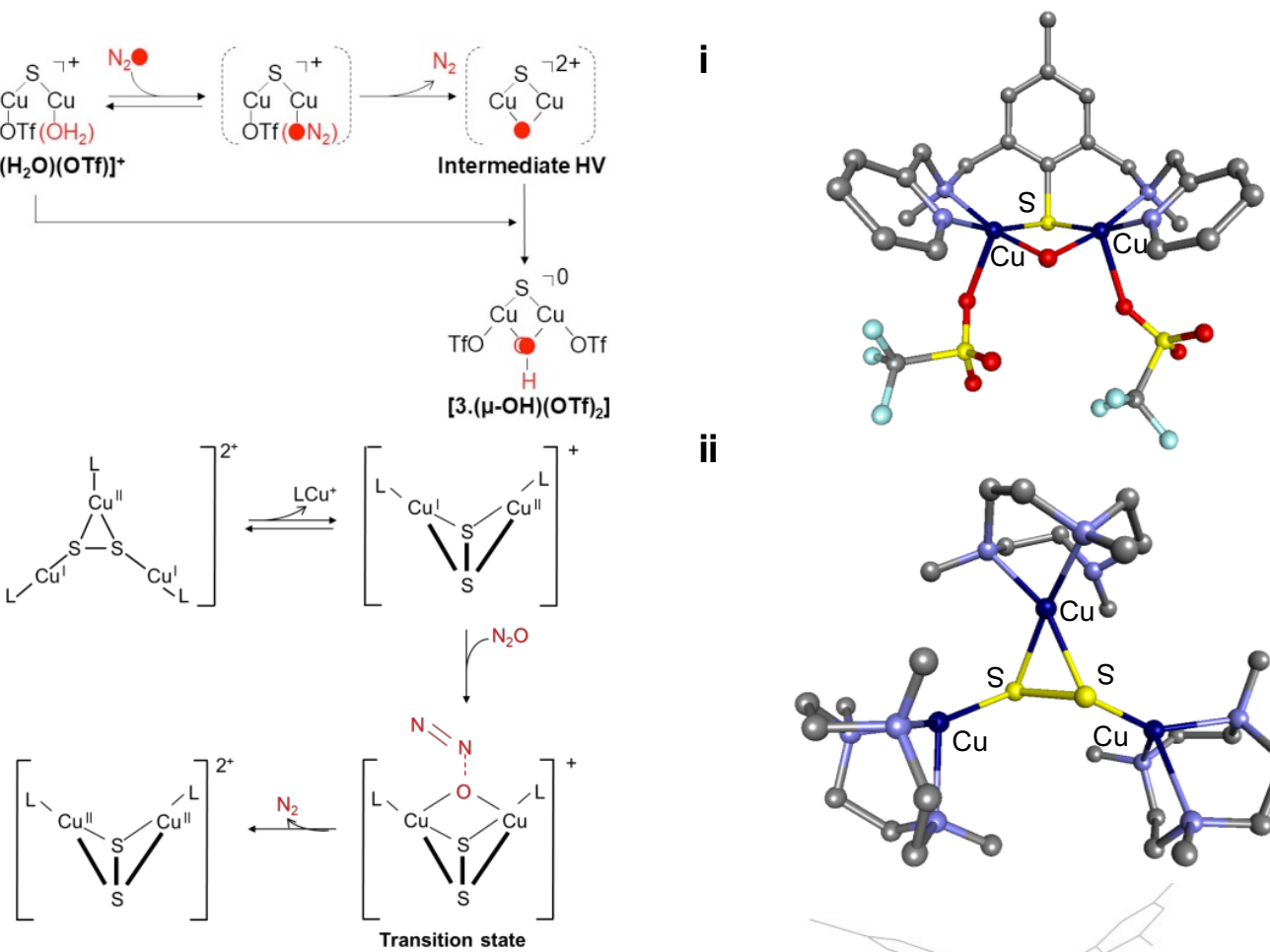

C

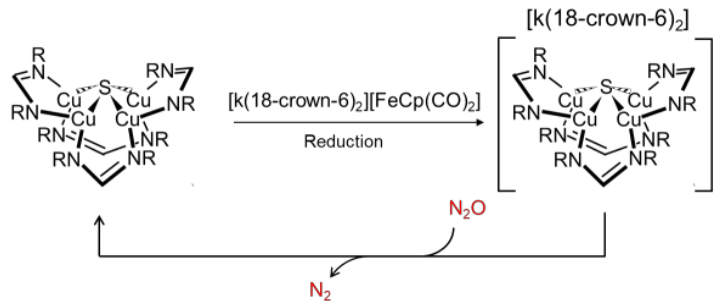

i

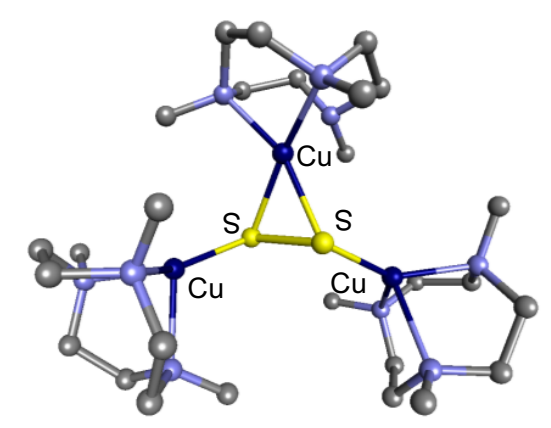

iii

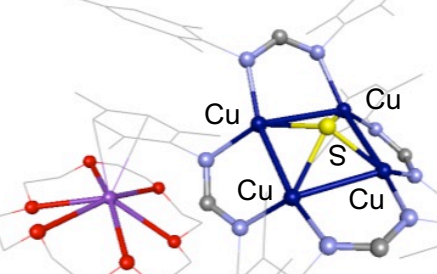

